\title{
Ecosystem Development After Mangrove Wetland Creation: Plant-Soil Change Across a 20-Year Chronosequence
}

\author{
Michael J. Osland, ${ }^{1,2 *}$ Amanda C. Spivak,,${ }^{1,3}$ Janet A. Nestlerode, ${ }^{1}$ Jeannine \\ M. Lessmann, ${ }^{4}$ Alejandro E. Almario, ${ }^{1}$ Paul T. Heitmuller, ${ }^{2}$ Marc J. Russell, ${ }^{1}$ \\ Ken W. Krauss, ${ }^{2}$ Federico Alvarez, ${ }^{1}$ Darrin D. Dantin, ${ }^{1}$ James E. Harvey, ${ }^{1}$ \\ Andrew S. From, ${ }^{5}$ Nicole Cormier, ${ }^{2}$ and Camille L. Stagg ${ }^{2}$
}

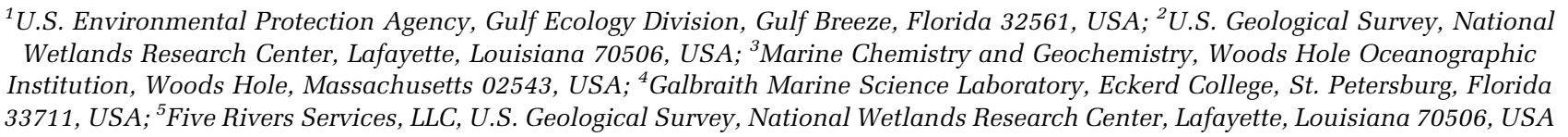

\begin{abstract}
Mangrove wetland restoration and creation efforts are increasingly proposed as mechanisms to compensate for mangrove wetland losses. However, ecosystem development and functional equivalence in restored and created mangrove wetlands are poorly understood. We compared a 20-year chronosequence of created tidal wetland sites in Tampa Bay, Florida (USA) to natural reference mangrove wetlands. Across the chronosequence, our sites represent the succession from salt marsh to mangrove forest communities. Our results identify important soil and plant structural differences between the created and natural reference wetland sites; however, they also depict a positive developmental trajectory for the created wetland sites that reflects tightly coupled plant-soil development. Because upland soils and/or dredge spoils were used to create the new mangrove habitats, the
\end{abstract}

Received 7 December 2011; accepted 15 April 2012;

published online 19 May 2012

Author Contributions: All authors helped develop the study design. MJO, ACS, JAN, JML, AEA, PTH, KWK, FA, DDD, NC, and ASF performed the research. MJO analyzed the data and served as the primary author. All authors contributed to the writing of the paper.

*Corresponding author; e-mail: mosland@usgs.gov soils at younger created sites and at lower depths $(10-30 \mathrm{~cm})$ had higher bulk densities, higher sand content, lower soil organic matter (SOM), lower total carbon (TC), and lower total nitrogen (TN) than did natural reference wetland soils. However, in the upper soil layer $(0-10 \mathrm{~cm}), \mathrm{SOM}, \mathrm{TC}$, and TN increased with created wetland site age simultaneously with mangrove forest growth. The rate of created wetland soil $\mathrm{C}$ accumulation was comparable to literature values for natural mangrove wetlands. Notably, the time to equivalence for the upper soil layer of created mangrove wetlands appears to be faster than for many other wetland ecosystem types. Collectively, our findings characterize the rate and trajectory of above- and below-ground changes associated with ecosystem development in created mangrove wetlands; this is valuable information for environmental managers planning to sustain existing mangrove wetlands or mitigate for mangrove wetland losses.

Key words: functional equivalency; carbon accumulation; succession; facilitation; wetland restoration; wetland creation; mangrove forest; salt marsh; Tampa Bay Florida. 


\section{INTRODUCTION}

In the last several decades, wetland restoration and creation efforts have been increasingly utilized to compensate for ecosystem goods and services lost due to wetland damage or removal. With proper planning and implementation, restoration and creation can help improve degraded landscapes by reestablishing wetlands at local and regional scales. However, there has been some concern and evidence that, within a regulatory or environmental management time frame (that is, years, decades), many restored and created wetlands are not becoming functionally equivalent to their natural counterparts (Zedler and Callaway 1999; Craft and others 2003; Bruland and Richardson 2006; Ballantine and Schneider 2009; Stagg and Mendelssohn 2010; Hossler and others 2011). Targeted decadal-scale research at restoration and creation sites has, to a certain extent, helped identify successful practices, detect shortcomings, and test and refine our understanding of wetland successional processes and functioning. However, decadal-scale research requires decadal-scale datasets, and our understanding of post-restoration and post-creation wetland ecosystem development and functional equivalence is limited by the availability of such data (Zedler 2000). As a result, we know more about wetland restoration and creation outcomes in some wetland ecosystem types (for example, salt marshes, freshwater marshes, prairie potholes) than in others where older sites are less prevalent or less studied. For example, despite the widespread interest in restoring mangrove wetlands, data quantifying successful restoration of mangrove wetland ecosystem functions are rare (but see: Ellison 2000; Lewis and Gilmore 2007; Bosire and others 2008; Lewis 2009).

Mangrove wetlands are highly productive salttolerant forested ecosystems distributed globally along sheltered tropical and subtropical coastlines (Tomlinson 1995). Despite the array of ecosystem goods and services supported by mangrove wetlands (for example, carbon [C] burial, fisheries habitat, forest products, erosion protection, water quality improvement; Ewel and others 1998; Barbier and others 2010; Spalding and others 2010), global mangrove wetland losses have been high in recent decades reaching approximately $0.7-1 \%$ global area loss per year primarily due to agricultural expansion, aquaculture, urbanization, and overharvesting (FAO 2007; Giri and others 2008; Spalding and others 2010; Giri and others 2011). In response, large-scale mangrove wetland restoration and creation efforts have been implemented in many parts of the world (Lewis 2005, 2009). However, due to insufficient design, monitoring, and long-term research, there is much to learn about the rate and trajectory of ecosystem development following mangrove wetland restoration and creation (reviewed by: Ellison 2000; Bosire and others 2008; Lewis 2009). In particular, we lack a developed understanding of how restored and created mangrove plant communities, soil properties, and soil-dependent ecosystem functions develop. Because prior work suggests that specific hydrologic regimes and natural plant recruitment processes are required for ensuring plant community development and long-term mangrove wetland restoration success (Kaly and Jones 1998; Lewis 2005; Friess and others 2011), ecosystemlevel studies that assess vegetation change via natural processes, as well as concomitant soil processes, play an important role in determining the viability and success of restoration and creation efforts.

Mangrove wetlands are among the most C-rich ecosystems on earth due to a combination of high primary productivity and slow microbial decomposition rates (Duarte and Cebrián 1996; Chmura and others 2003; Donato and others 2011). Some mangrove wetlands have layers of organic matter (that is, peat) that extend several meters or more beneath the soil surface (McKee and others 2007a; Donato and others 2011), and high plant productivity (for example, root production, surficial mat formation) in natural mangrove ecosystems can drive relatively rapid gains in soil accumulation in some settings (Middleton and McKee 2001; McKee and others 2007a; McKee 2010). Prior research has examined mangrove forest and soil development on newly available substrates (for example, smothered coral reefs and rapidly accreting shorelines: Alongi and others 2008; Lovelock and others 2010, respectively) and in mangrove forest plantations managed for wood production (Alongi and others 2001; Morrisey and others 2003; Alongi and others 2004; Ren and others 2008; Alongi 2011). However, to our knowledge, there are only two studies that have compared soil properties and/or soil processes in natural to restored or created mangrove wetland ecosystems (McKee and Faulkner 2000; Vovides and others 2010).

In this study, we used a 20-year chronosequence of created tidal wetlands in Tampa Bay, Florida (USA) to investigate the rate and trajectory of ecosystem development following mangrove wetland creation. We compared created wetlands of different ages (2-20 years) with natural reference 
wetlands. Created tidal wetlands in Tampa Bay are often excavated to an acceptable tidal datum and planted with native salt marsh grasses to create immediate structural habitat, stabilize substrates, and accelerate secondary succession (Lewis and Dunstan 1975; Lewis 1982). Based upon reports for the region indicating high natural mangrove recruitment in created tidal wetlands and highlighting the potential facilitative role that salt marsh grasses can play during mangrove forest development (Lewis and Dunstan 1975; Crewz and Lewis 1991; Lewis and others 2005; Shafer and Roberts 2008; Smith and others 2009), we expected that within the 20-year chronosequence represented by our data, the created tidal wetland sites would successfully transition from salt marsh to mangrove forest. Our vegetation measurements compared structural properties in created and natural mangrove wetlands quantifying the rate and trajectory of the salt marsh to mangrove forest transition. Our soil measurements focused upon metrics related to peat development following mangrove wetland creation; we quantified soil $\mathrm{C}$ and nitrogen $(\mathrm{N})$ accumulation after mangrove wetland creation and compared the soil $\mathrm{C}$ and $\mathrm{N}$ pools in created and natural mangrove wetlands. Given the potential for relatively rapid plant-driven soil change and $\mathrm{C}$ accumulation in natural mangrove wetlands (McKee 2010; Mcleod and others
2011), our hypotheses were that soil change in created mangrove wetlands would be relatively rapid compared to other created and restored wetland types and that created mangrove wetland soil change would be plant-driven and tightly linked to mangrove forest growth.

In a broad sense, our research addresses the following three questions: (1) how similar are created and natural mangrove wetland ecosystems; (2) how quickly do mangrove wetland plant and soil properties develop after creation; and (3) how does the rate and trajectory of ecosystem development in created mangrove wetlands compare to other tidal and non-tidal created and restored wetland ecosystem types?

\section{MeThodS}

\section{Study Area}

This research was conducted in tidal saline wetlands within Tampa Bay, Florida, USA during June-August 2010. Tampa Bay is Florida's largest open-water estuary and is located along the Gulf of Mexico coastline in the west-central portion of the state (Figure 1). Tampa Bay is a subtropical estuary that contains both mangrove forest and salt marshdominated tidal saline wetlands. However, mangrove forests are more common than salt marshes

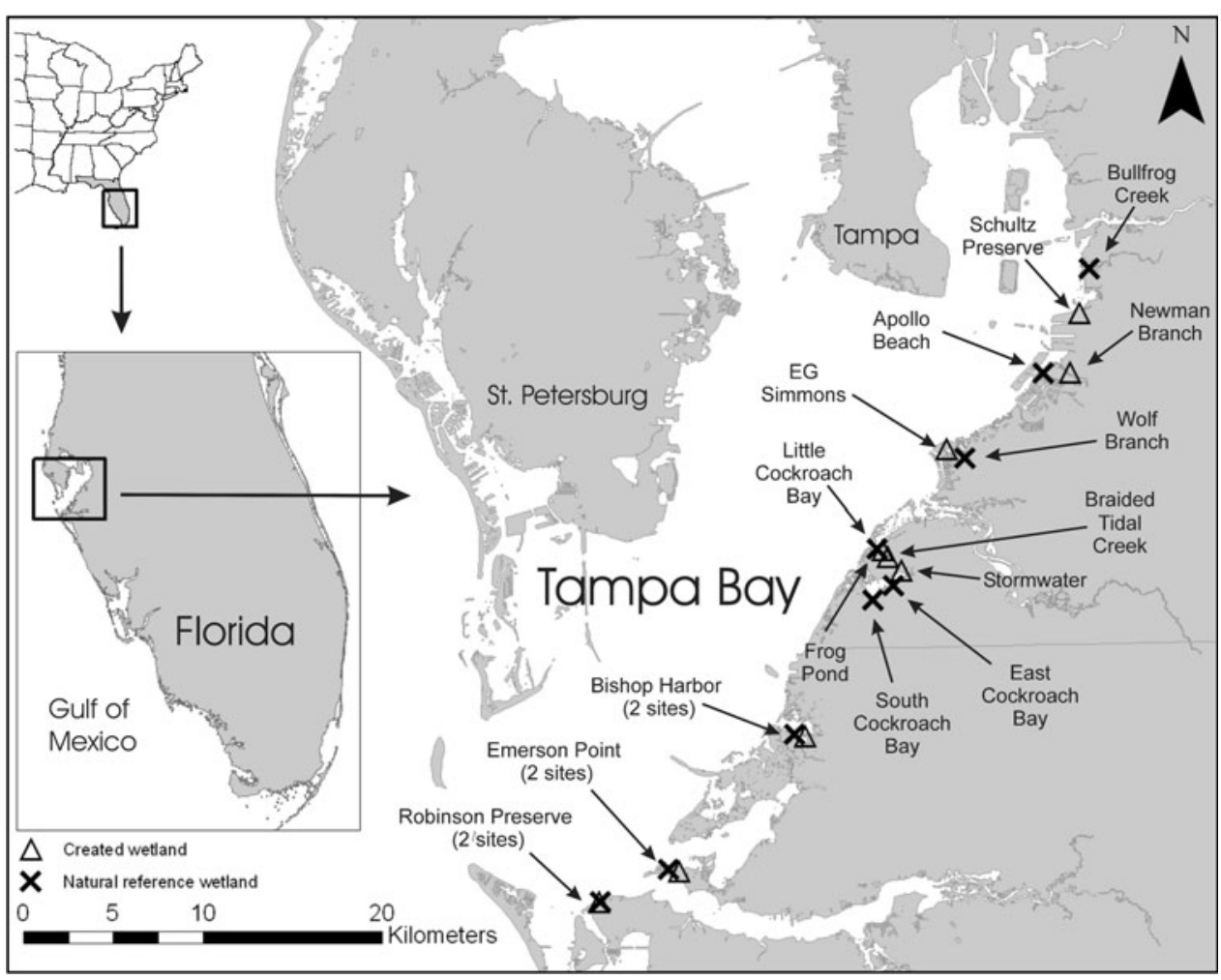

Figure 1. Map of Tampa Bay, Florida identifying the location of the 18 created and natural reference wetlands included in this study. 
in Tampa Bay; Lewis and Estevez (1988) estimated that only $20 \%$ of Tampa Bay tidal wetlands were dominated by salt marsh species. Our sites were located along the southeastern shoreline of the estuary (Figure 1) in Hillsborough and Manatee Counties. Sites spanned the following latitudes $(\mathrm{N})$ and longitudes $(\mathrm{W}): 27.519^{\circ}-27.835^{\circ}$ and $82.673^{\circ}-$ $82.391^{\circ}$, respectively.

\section{Experimental Design}

Our experimental design utilized a chronosequence approach (that is, space-for-time substitution; Pickett and Ostfeld 1989) to investigate ecosystem development after tidal wetland creation. We selected nine created tidal wetlands that together form a twenty-year chronosequence (1990-2010), as well as nine mangrove wetland ecosystems to represent the natural reference sites for our created wetlands (Table 1; see Figures 2, 3 for before and after wetland creation aerial photos and photos of soil and vegetation change along the chronosequence, respectively). To account for spatial variability within the study region, each of the nine natural reference wetland sites was located in close proximity to a created wetland site (Figure 1). At each of the 18 sites, we established three $100-\mathrm{m}^{2}$ plots, and, within each $100-\mathrm{m}^{2}$ plot, we randomly located two $4-\mathrm{m}^{2}$ subplots, three $1-\mathrm{m}^{2}$ subplots, and three $0.25-\mathrm{m}^{2}$ subplots, each designated for a specific suite of soil and/or vegetation measurements.

\section{Vegetation}

Within each of the three $100-\mathrm{m}^{2}$ plots at each site, vegetation measurements were conducted for three strata: the herbaceous layer, the juvenile mangrove tree layer, and the adult mangrove tree layer. For the herbaceous layer, we measured species-specific percent cover in each of the three $1-\mathrm{m}^{2}$ subplots randomly located within each $100-\mathrm{m}^{2}$ plot. We quantified herbaceous aboveground biomass and stem density within each $100-\mathrm{m}^{2}$ plot via a single composite sample consisting of aboveground clipplots from each of the three $0.25-\mathrm{m}^{2}$ subplots randomly located within each $100-\mathrm{m}^{2}$ plot. For the juvenile mangrove tree layer (defined as individuals whose height was greater than $0.3 \mathrm{~m}$ but smaller than $3 \mathrm{~m}$ ), we measured the height of each individual typically within the two randomly established $4-\mathrm{m}^{2}$ subplots within each $100-\mathrm{m}^{2}$ plot. However, at many of the created wetlands, the juvenile mangrove tree densities were so high that logistical constraints prevented us from obtaining juvenile mangrove tree measurements within the
4- $\mathrm{m}^{2}$ subplots and measurements were instead taken in the $1-\mathrm{m}^{2}$ subplots. To verify that the densities measured in these $1-\mathrm{m}^{2}$ subplots were indicative of measurements in the $4-\mathrm{m}^{2}$ subplots, we measured and compared the densities present within both subplot sizes for $33 \%$ of the juvenile mangrove tree data collected from $1-\mathrm{m}^{2}$ subplots and determined a strong relationship between juvenile mangrove tree density measurements in the two subplot sizes $\left(R^{2}=0.90 ; P<0.0001\right)$. For the adult mangrove tree layer, we measured the diameter at breast height (DBH) of each individual adult tree (defined as individuals with a DBH of at least $6 \mathrm{~cm}$ ) present within each $100-\mathrm{m}^{2}$ plot.

\section{Soil}

Within each of the three $100-\mathrm{m}^{2}$ plots at each site, we collected a total of four soil cores to $30-\mathrm{cm}$ depth using a customized stainless steel split-coring cylinder (diameter: $4.7 \mathrm{~mm}$; cylinder was split horizontally and a piano hinge was attached to facilitate opening and closing). Each $30-\mathrm{cm}$ core was stratified into two sampling depths: $0-10 \mathrm{~cm}$ and $10-30 \mathrm{~cm}$. One of the four cores was collected solely for bulk density determination, and three additional cores were collected and composited for all other analyses (the latter cores are referred to as multi-analysis cores). The multi-analysis cores were collected from within a $1-\mathrm{m}$ buffer surrounding each of the three randomly located $1-\mathrm{m}^{2}$ subplots within each $100-\mathrm{m}^{2}$ plot (that is, one core was collected per $1-\mathrm{m}^{2}$ subplot buffer; total of three multi-analysis cores collected per $100-\mathrm{m}^{2}$ plot). Sections from the three multi-analysis cores were pooled into two depth-specific composite samples for each $100-\mathrm{m}^{2}$ plot (that is, one $0-10 \mathrm{~cm}$ composite sample and one $10-30 \mathrm{~cm}$ composite sample). Soil samples were stored on ice after extraction, refrigerated $\left(\sim 4^{\circ} \mathrm{C}\right)$ until transport, and transported on ice to the U.S. EPA Gulf Ecology Division (Gulf Breeze, Florida). Soil bulk density was determined as a simple dry weight to volume ratio (Blake and Hartge 1986). Soil moisture was determined via water loss upon drying. Soil $\mathrm{pH}$ was measured on a field-moist fraction. Prior to all other analyses, the multi-analysis samples were sieved (4-mm mesh), dried, and homogenized with an analytical mill. Soil total C (TC) and total nitrogen (TN) were measured via dry combustion (McGill and Figueiredo 1993; Tiessen and Moir 1993). Soil organic matter (SOM) was determined via loss on ignition (Karam 1993). Soil particle size distribution (that is, percent sand, silt, and clay content) was measured via laser diffraction (Eshel 


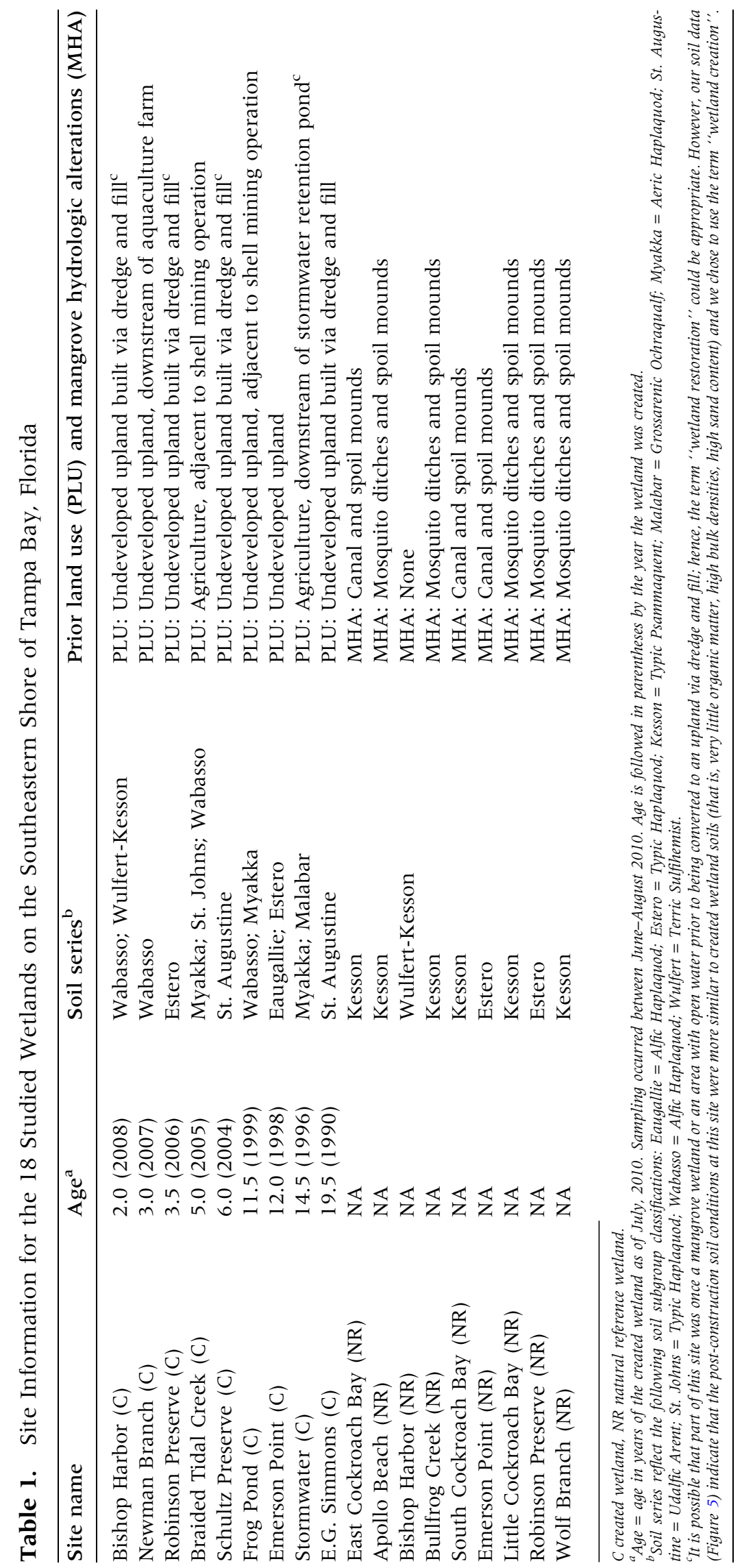



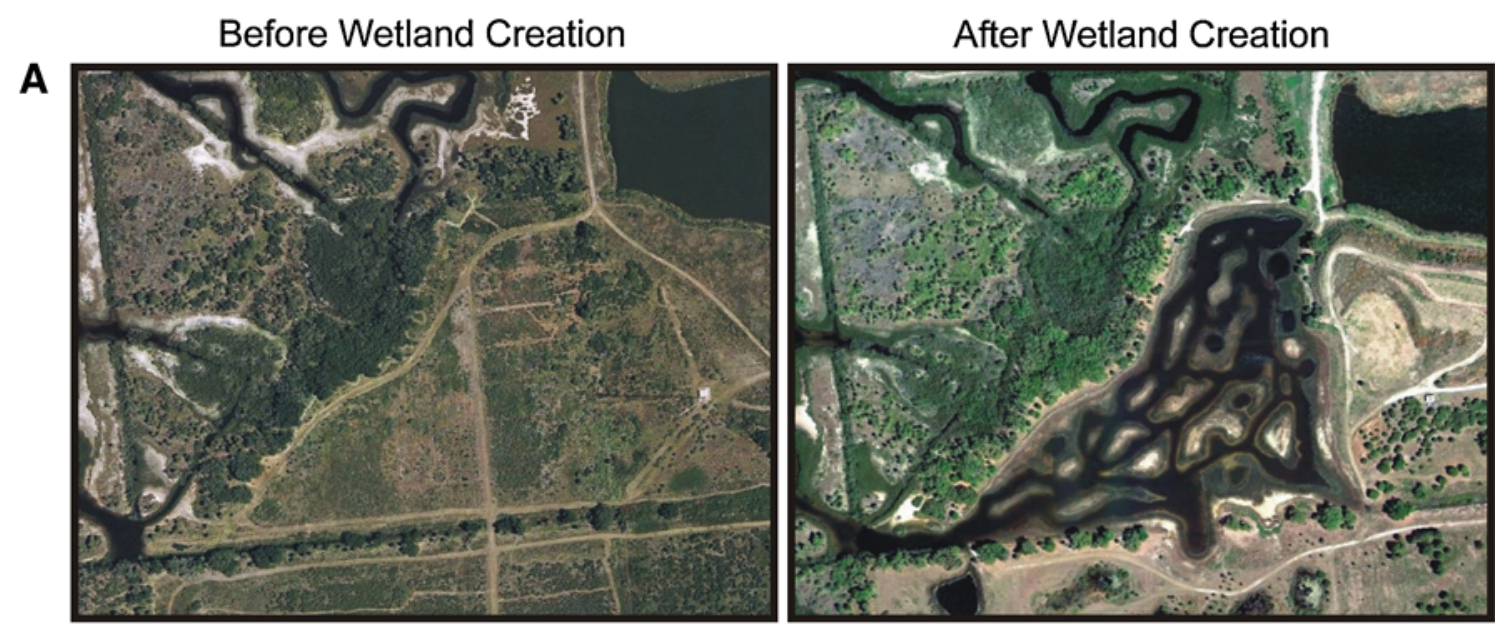

B
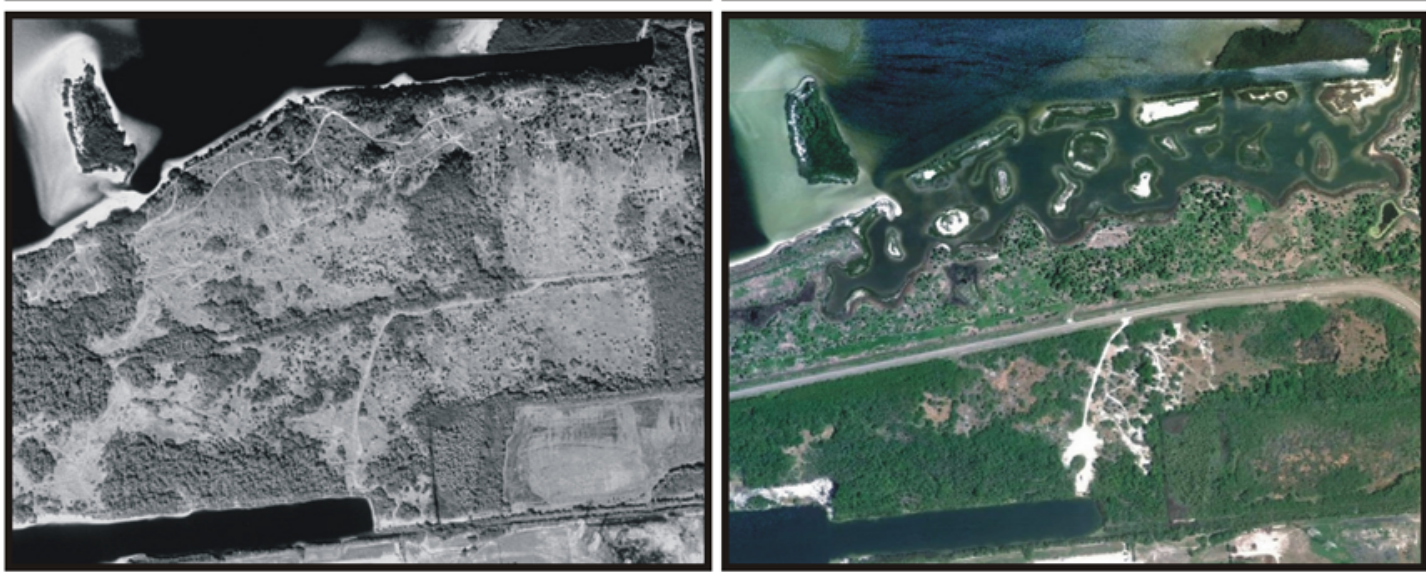

C
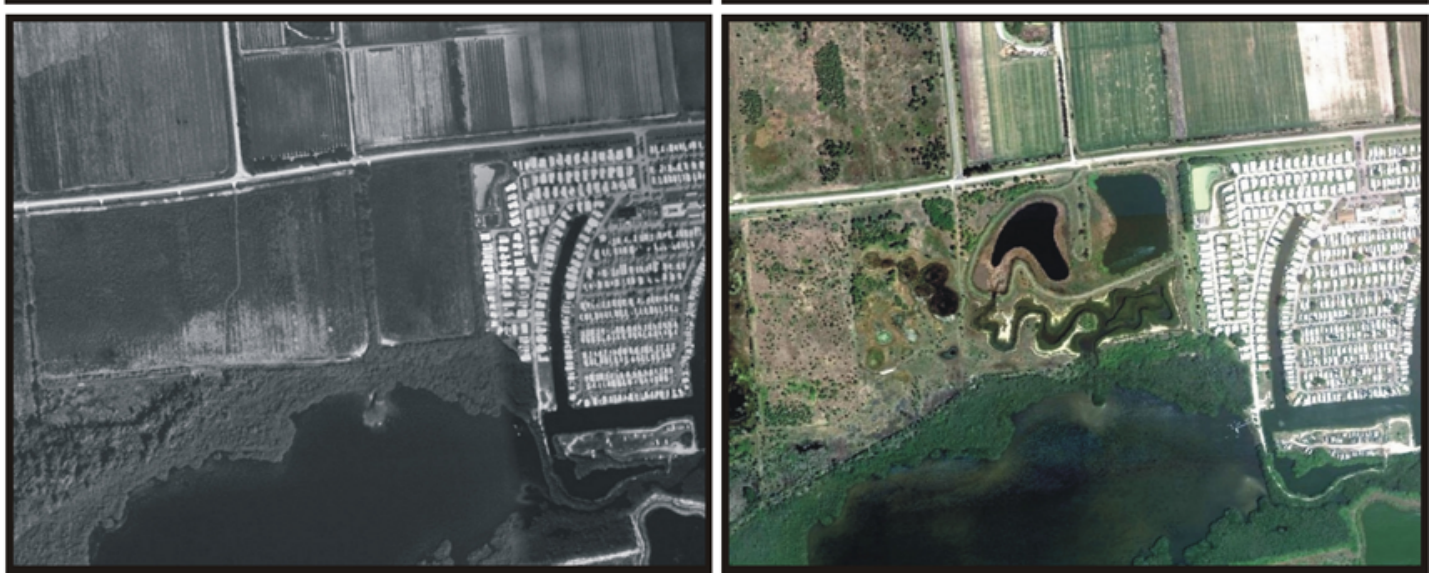

Figure 2. Before and after wetland creation aerial photos for the following three sites in Tampa Bay, Florida: A Braided Tidal Creek, near Cockroach Bay; B Schultz Preserve, north of Apollo Beach; and C Stormwater, near Cockroach Bay.

and others 2004). The soil TC, TN, pH, and particle size analyses were conducted by the Watershed Diagnostics Research Branch of the U.S. EPA's MidContinent Ecology Division.

To determine soil $\mathrm{C}$ and $\mathrm{N}$ accumulation rates, we quantified the relationship between site age and soil $\mathrm{C}$ and $\mathrm{N}$ pools in the top $10 \mathrm{~cm}$ of created mangrove wetlands. The rate of change in the resultant equations represents the $\mathrm{C}$ and $\mathrm{N}$ accumulation rates $\left(\mathrm{g} \mathrm{m}^{-2} \mathrm{y}^{-1}\right)$ within the upper soil layer of created mangrove wetland sites. Note that one created wetland site (Bishop Harbor, a 2-year old site) was treated as an outlier and excluded from the $\mathrm{C}$ accumulation calculations due to an abnormally high initial TC pool $\left(3270 \pm 630 \mathrm{~g} \mathrm{~m}^{-2}\right)$ which was likely due to high inorganic $\mathrm{C}$ 


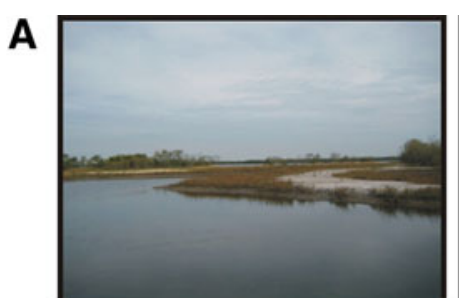

B

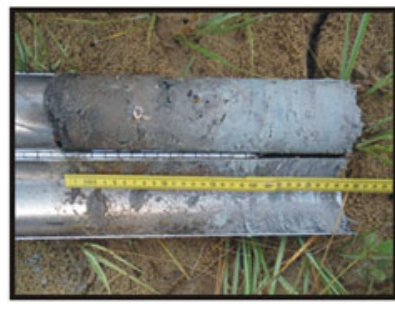

0 years
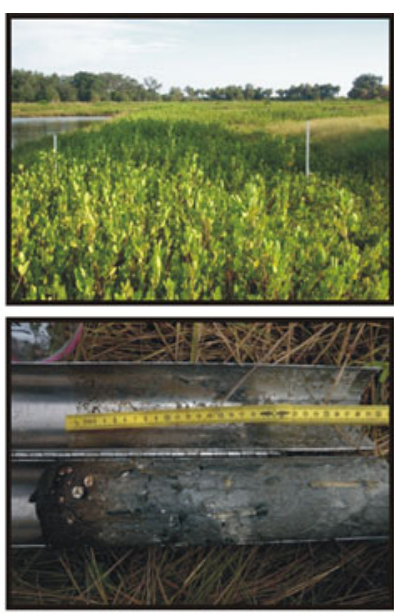

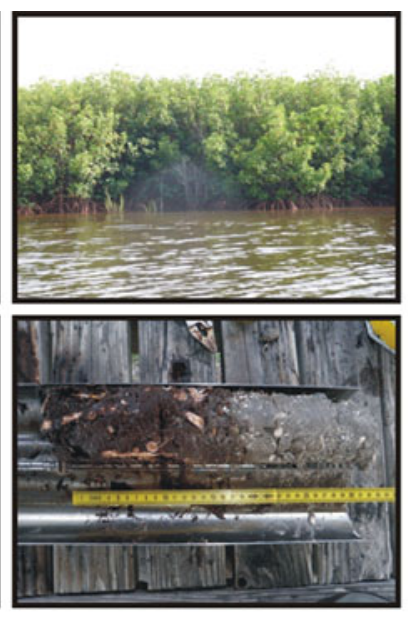

20 years

Increasing time since wetland creation

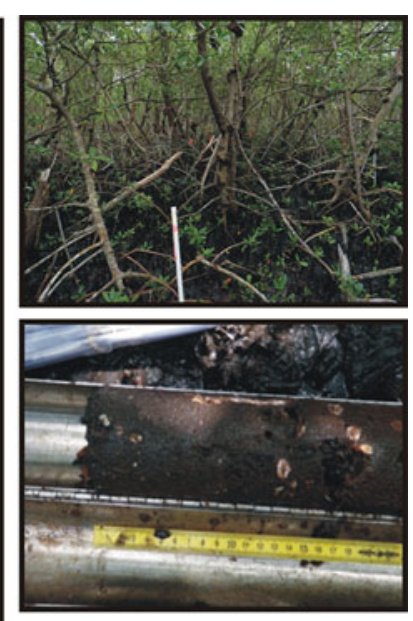

Reference

Figure 3. Photos depicting the vegetation and soil change across the 20-year chronosequence: (A) vegetation transition from salt marsh to mangrove forest; and (B) concomitant peat development. The vegetation and dark, deep peat layer from a natural reference mangrove forest are included to illustrate visible differences between the created and natural reference wetlands.

contributions incorporated into the soil before or during site creation. There was not a deep peat layer present in Bishop Harbor soils and soil samples from the site had very high TC to SOM ratios (mean $\pm \mathrm{SE}=1.23 \pm 0.30$ ) which are indicative of high inorganic $\mathrm{C}$. For comparison, the mean $\pm \mathrm{SE}$ TC to SOM ratio for all other sites was $0.48 \pm 0.02$.

\section{Porewater}

Within a $1-\mathrm{m}$ buffer surrounding each of the three $1-\mathrm{m}^{2}$ subplots associated with a single $100-\mathrm{m}^{2}$ plot at each site, an unfiltered $50-\mathrm{ml}$ porewater sample was collected from a depth of $30 \mathrm{~cm}$ using a sipper tube apparatus (McKee and others 1988) for in situ $\mathrm{pH}$, salinity, and temperature measurements using a hand-held meter (YSI Model 63, Yellow Springs Instruments Inc., Yellow Springs, Ohio, USA).

\section{Data Analyses}

Means \pm SE were calculated for all dependent variables for each site ( $n=3$ per site). We used simple linear and nonlinear regression to quantify soil and vegetation relationships with created wetland site age. Using the resultant regression equations and the natural reference wetland means (that is, mean of nine natural reference sites), we calculated the amount of time required for a created wetland to become equivalent to a natural mangrove wetland (time to equivalence or $t_{\mathrm{eq}}$ ) for each ecosystem property. The starting point for our time to equivalency calculations is the moment that tidal wetland creation activities were completed. To determine the effect of wetland type and soil depth upon soil properties, we used ANOVAs that included wetland type (created or natural), soil depth $(0-10 \mathrm{~cm}$ or $10-30 \mathrm{~cm})$, and their interaction. We used Spearman rank correlations to assess bivariate relationships between soil, porewater $\mathrm{pH}$, and vegetation measurements. We quantified multivariate relationships between plant and soil properties using principal components analyses (PCA) of the following two data matrices: (1) a site by soil matrix that contained site-level soil physicochemical data (that is, bulk density, SOM, sand content, $\mathrm{pH}, \mathrm{TC}, \mathrm{TN}$, moisture content); and (2) a site by vegetation matrix that contained site-level herbaceous, juvenile mangrove tree, and adult mangrove tree data (that is, the following plant structural measurements: Spartina alterniflora biomass, S. alterniflora stem density, juvenile mangrove tree height, juvenile mangrove tree density, adult mangrove tree diameter, adult mangrove tree density). To improve normality, we log-transformed the following variables prior to PCA: S. alterniflora biomass, S. alterniflora stem density, juvenile mangrove tree density, and juvenile mangrove tree height. We tested for significant axes via broken-stick model eigenvalue comparisons. ANOVAs and Spearman rank correlations 
were conducted using SAS Version 9.1.3 (SAS Institute, Cary, NC, USA). PCA was conducted using PC-ORD Version 5.10 (MjM Software Design, Gleneden Beach, OR, USA.; McCune and Grace 2002).

Finally, we developed a simple model for evaluating the amount of time and area required for $\mathrm{C}$ burial in restored and created mangrove wetlands to compensate for $\mathrm{C}$ burial lost due to past mangrove wetland losses using the following data: (1) global mangrove forest loss estimates (Spalding and others 2010); (2) the global mean C burial rate from natural mangrove wetlands (Mcleod and others 2011); and (3) the C burial rate determined from this study.

\section{RESULTS}

Vegetation Change After Mangrove Wetland Creation and Differences Between Created and Natural Mangrove Wetlands

Across the 20-year created wetland chronosequence, the vegetation transitioned from a planted herbaceous layer dominated by $S$. alterniflora to a mangrove forest community dominated by Rhizophora mangle, Laguncularia racemosa, and/or Avicennia germinans. Whereas the natural reference wetlands contained mangrove forests with no herbaceous layer, the younger created wetlands ( $<5$-years-old) had an herbaceous salt marsh layer that was dominated almost entirely by S. alterniflora (Figure 4; compositional data not shown). Aboveground biomass and stem density of $S$. alterniflora in the created wetlands was highest during the first 5 years, but $S$. alterniflora was absent from all sites by about the 13th year, decreasing with increasing site age simultaneously with the increase in height and density of juvenile mangrove trees (Figure 4). Percent cover of $S$. alterniflora exhibited a similar site-age relationship as that of $S$. alterniflora biomass and stem density (data not shown; $R^{2}=0.89$ and 0.89 , respectively). Time to equivalence for both S. alterniflora biomass and stem density in the created wetlands was estimated to be 13 years (Figure 4). Natural recruitment of mangrove individuals was initially high and the density and height of juvenile mangrove trees increased with site age during the first 5 and 15 years, respectively (Figure 4). Time to equivalence for juvenile mangrove tree height and juvenile mangrove tree density in the created wetlands was estimated to be 21 and 17 years, respectively (Figure 4). Density and diameter of adult mangrove trees increased rapidly in the second decade of the chronosequence but had not yet become equivalent to natural mangrove forests; time to equivalence for adult mangrove tree diameter and density was estimated to be 25 and 55 years, respectively (Figure 4).

\section{Soil Change After Mangrove Wetland Creation and Differences Between Created and Natural Mangrove Wetlands}

Across the 20-year created wetland chronosequence, a peat layer developed in the upper $10-\mathrm{cm}$ of soil (Figures 3, 5). Upper soil layers of created wetlands exhibited a significant relationship between all of the soil properties we measured and site age; whereas bulk density and sand content in the upper layer decreased with site age, moisture, SOM, TC, and TN increased with site age (Figure 5). Calculated times to equivalence (years) for soil properties in the upper soil layer of created wetlands were as follows: bulk density (25), sand content (18), moisture content (28), SOM (20), TC (20), and TN (19) (Figure 5). Soil C and N accumulation rates in the upper layer of created mangrove wetlands were calculated to be 218 and $13 \mathrm{~g} \mathrm{~m}^{-2} \mathrm{y}^{-1}$, respectively (Figure 6). For the lower soil layer of created wetlands, there was no relationship between the soil properties we measured and site age (that is, no soil change in the lower-layer across the 20-year chronosquence; Figure 5).

For both types of wetlands (that is, created and natural), soil properties in the upper soil layer $(0-10 \mathrm{~cm})$ differed from those in the lower soil layer $(10-30 \mathrm{~cm})$; soil from the upper layer had lower bulk densities, lower sand content, higher moisture content, higher SOM, higher TC, and higher TN (Table 2; Figure 5). When compared collectively (that is, created versus natural reference wetlands, independent of site age), created wetlands differed from natural reference wetlands for every soil property we measured within both the upper and lower soil layers; created wetland soils had higher bulk densities, higher sand content, lower moisture content, lower SOM, lower $\mathrm{TC}$, lower TN, and higher $\mathrm{pH}$ (Table 2; Figure 5).

\section{Porewater Differences Between Created and Natural Mangrove Wetlands}

There was no significant relationship between created wetland site age and porewater salinity, temperature, or $\mathrm{pH}$ (data not shown). However, created wetlands had significantly higher porewater temperatures and $\mathrm{pH}$ relative to natural 

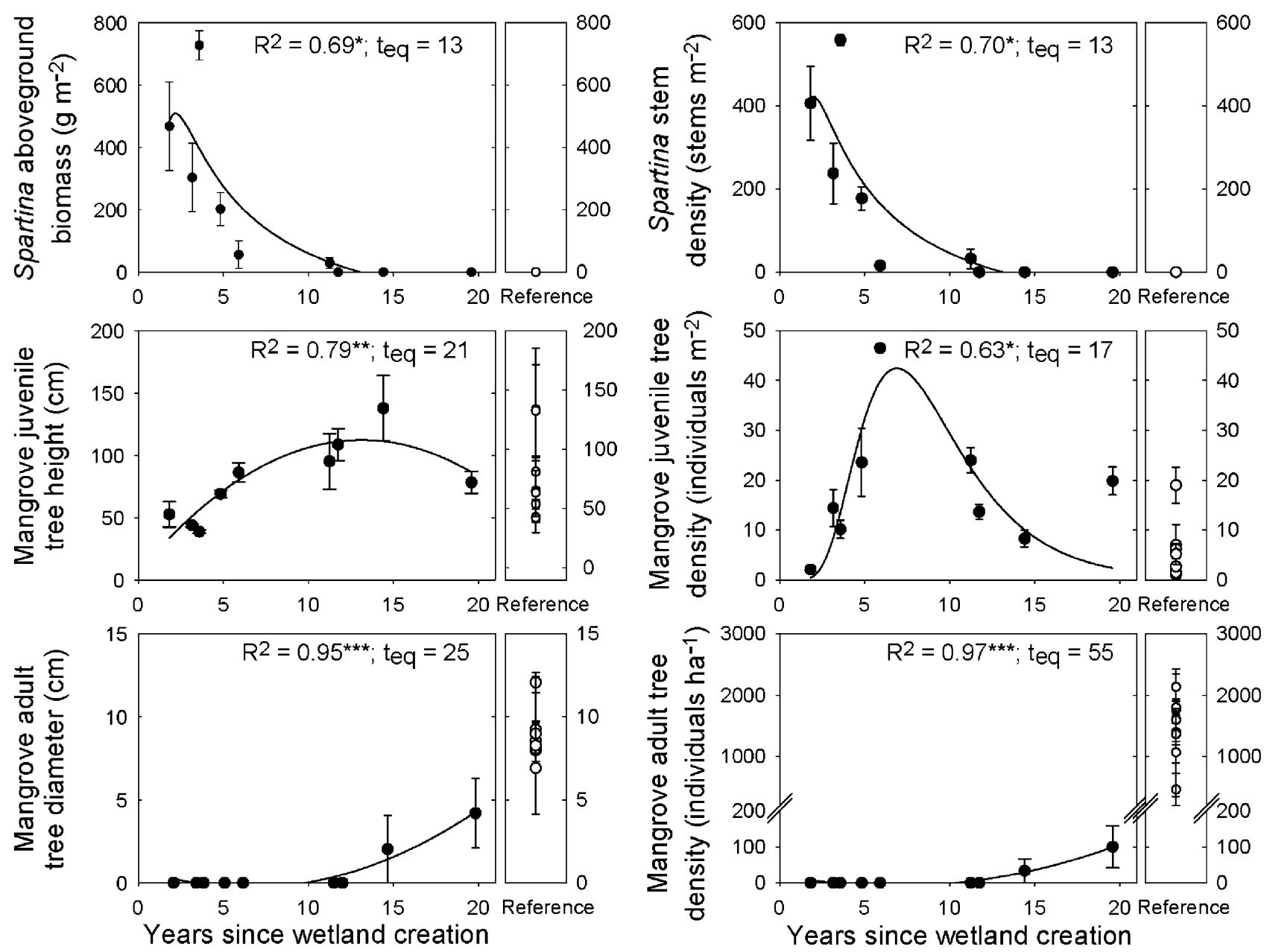

Figure 4. Site-level plant structural characteristics for created and natural reference wetlands (mean \pm SE). For the created wetlands, site structural properties are shown relative to site age. For significant structure-age relationships, the strength of the relationship and the time to equivalence $\left(t_{\mathrm{eq}}\right)$ are shown. Asterisk represent level of significance: ${ }^{*} P<0.05$; $* * P<0.01 ; * * * P<0.001$.

reference wetlands; the mean porewater temperature for created and natural reference wetlands was $30.6 \pm 0.5$ and $28.7 \pm 0.5^{\circ} \mathrm{C}$, respectively $(P<$ $0.05)$, and the mean porewater $\mathrm{pH}$ was $6.64 \pm 0.03$ and $6.15 \pm 0.07$, respectively $(P<0.001)$. There was no significant difference between porewater salinity in the created and natural reference wetlands $(30.0 \pm 1.3$ and $32.9 \pm 2.3 \mathrm{ppt}$, respectively; $P=0.29)$.

\section{Coupled Plant and Soil Change Across the 20-Year Chronosequence}

A PCA of the site by soil data matrix produced one significant axis (referred to as Soil-PCl) that accounted for $83 \%$ of the variance and was strongly related to soil bulk density, $\mathrm{pH}$, sand content, moisture content, SOM, TN, and TC (eigenvectors: $0.40,0.31,0.34,-0.41,-0.39$,
-0.39 , and -0.40 , respectively). The PCA of the site by vegetation structure data matrix produced one significant axis (referred to as Vegetation-PC1) that accounted for $60 \%$ of the variance and was strongly related to $S$. alterniflora biomass, S. alterniflora stem density, juvenile mangrove tree height, juvenile mangrove tree density, adult mangrove tree diameter, and adult mangrove tree density (eigenvectors: $0.47,0.47,-0.02,0.30,-0.49$, and -0.49 , respectively). A biplot of these two soil and vegetation principal component axes site scores illustrates the strong relationship between site soil and vegetation properties as well as the simultaneous soil and vegetation change that occurs across the 20-year chronosequence (Figure 7). Spearman correlations also highlight the strong relationships between vegetation structure and the soil and porewater properties; notably, all vegetation 

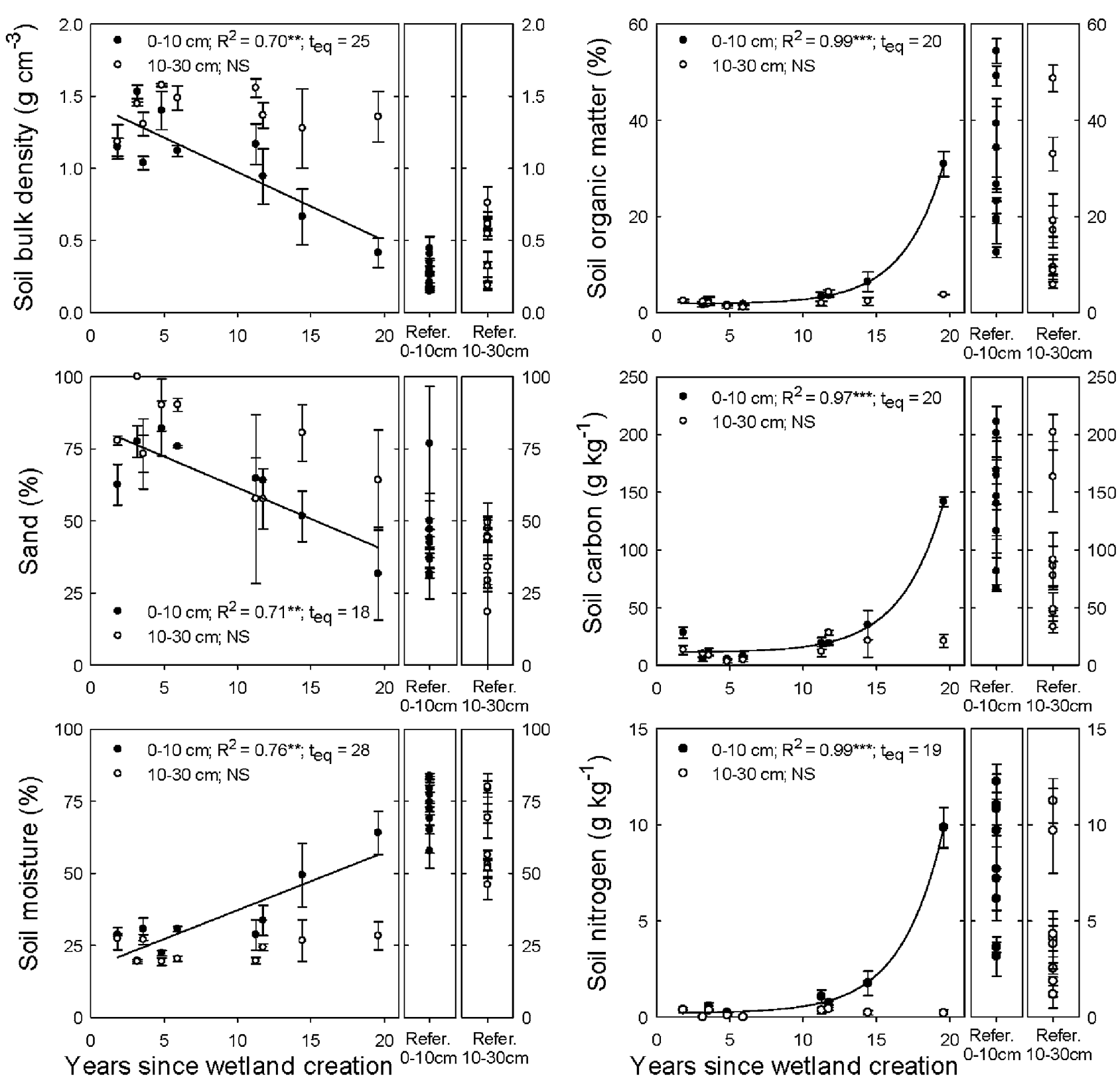

Figure 5. Site-level soil physical and chemical properties for created and natural reference wetlands at two depths (0$10 \mathrm{~cm}$ and $10-30 \mathrm{~cm}$; mean $\pm \mathrm{SE}$ ). For the created wetlands, site soil properties are shown relative to site age. For significant soil-age relationships $(0-10 \mathrm{~cm})$, the strength of the relationship and the time to equivalence $\left(t_{\text {eq }}\right)$ are shown. For non-significant soil-age relationships $(10-30 \mathrm{~cm})$, the time to equivalence is unknown. For both wetland types, soil properties in the upper soil layer $(0-10 \mathrm{~cm})$ differed significantly from the lower soil layer $(10-30 \mathrm{~cm})$. NS not significant. Asterisks represent level of significance: ${ }^{*} P<0.05 ; * * P<0.01$; ${ }^{* *} P<0.001$.

parameters were well correlated with soil OM, TC, $\mathrm{TN}$, and bulk density (Table 3 ).

\section{DisCuSSION}

The intent of wetland restoration and creation is often to replace ecosystem functions and services that were lost during wetland degradation or conversion to other land uses. Many wetland restoration and creation efforts are implemented with the assumption that once a site is restored or created, it will develop along a predictable trajectory and become equivalent to a natural wetland at some point in the future for a particular suite of ecosystem 

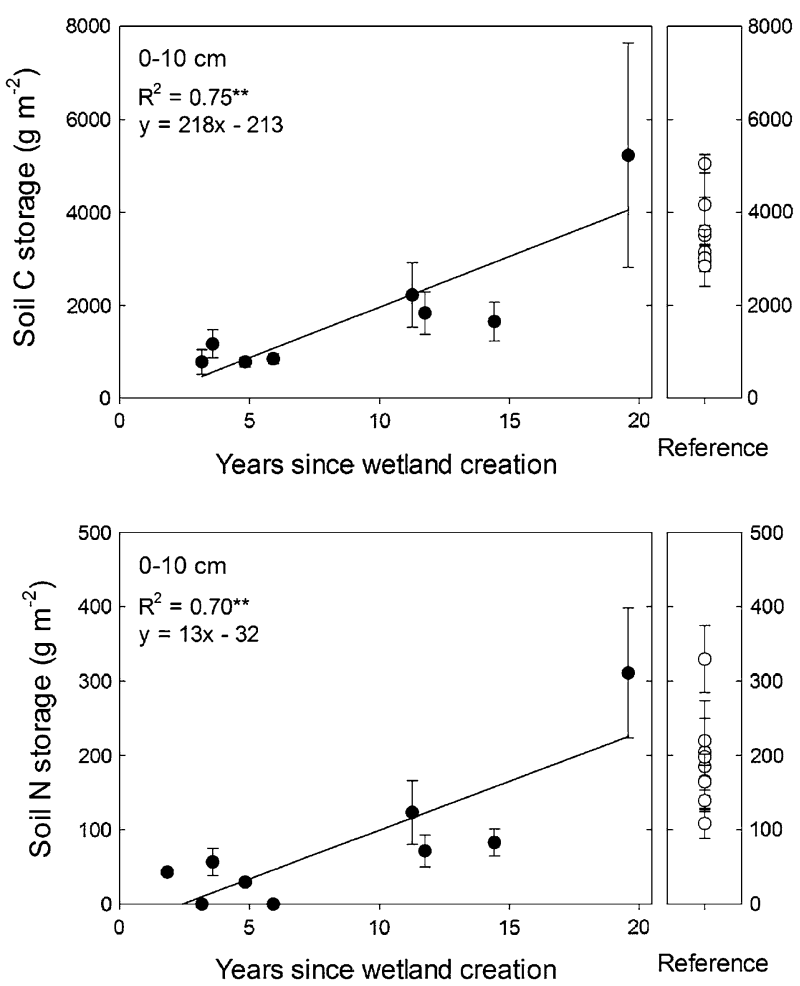

Figure 6. Site-level soil $\mathrm{C}$ and $\mathrm{N}$ storage in the upper soil layer $(0-10 \mathrm{~cm})$ of created and natural reference wetlands (mean $\pm \mathrm{SE}$ ). For the created wetlands, site soil $\mathrm{C}$ and $\mathrm{N}$ storage is shown relative to site age.

functions or services. However, many restoration and creation efforts do not follow predicted trajectories or are nonlinear (Zedler 1996; Zedler and Callaway 1999; Matthews and Spyreas 2010; Hossler and others 2011), and where a trajectory is present, ecosystem properties typically develop differentially (Zedler 2000; Craft and others 2003). For example, whereas processes linked to hydrology can be restored relatively rapidly with proper design (for example, within the first year) (Craft and others 2003; Lewis 2005), soil-dependent properties and processes often require much more time to reach equivalency (for example, decades, centuries) (Craft and others 2003; Ballantine and Schneider 2009; Hossler and Bouchard 2010). Furthermore, the rate and trajectory of ecosystem development also varies due to wetland type, landscape position, land-use history, and site-specific starting conditions (Bedford and others 1999; Zedler 2000; Ballantine and Schneider 2009). In this study, we quantified the rate and trajectory of soil and vegetation change following mangrove wetland creation in Tampa Bay, Florida.

\section{Mangrove Establishment After Wetland Creation: the Transition from Salt Marsh to Mangrove Forest and the Potential Role of Positive Interactions}

Due to their position at the land-sea interface, mangrove ecosystems are governed by highly stressful and dynamic abiotic conditions (for example, fluctuating anaerobic/aerobic soils; variable salinity; submergence/desiccation; moving water). These extreme conditions greatly influence the establishment and development of mangrove plant communities (Krauss and others 2008), and many mangrove wetland restoration efforts have failed due to poor survival and growth of mangrove individuals that were planted at inappropriate tidal elevations and/or in excessively stressful conditions (Lewis 2005, 2009). Several studies have suggested that, once the appropriate hydrologic regime is established (see Lewis 2005), mangrove wetland restoration efforts are likely to benefit from the incorporation of positive biotic interactions that alleviate stressful conditions impacting plant

Table 2. Effect of Wetland Type and Soil Depth Upon Soil Properties (Mean \pm SE), Independent of Site Age

\begin{tabular}{|c|c|c|c|c|c|c|}
\hline \multirow[t]{2}{*}{ Soil Property } & \multicolumn{2}{|l|}{ Created } & \multicolumn{2}{|l|}{ Natural } & \multirow[t]{2}{*}{ Wetland type } & \multirow[t]{2}{*}{ Soil depth } \\
\hline & $0-10 \mathrm{~cm}$ & $10-30 \mathrm{~cm}$ & $0-10 \mathrm{~cm}$ & $10-30 \mathrm{~cm}$ & & \\
\hline Bulk density $\left(\mathrm{g} \mathrm{cm}^{-3}\right)$ & $1.05 \pm 0.11$ & $1.40 \pm 0.04$ & $0.28 \pm 0.04$ & $0.47 \pm 0.07$ & $136.7 * * *$ & $13.7 * * *$ \\
\hline Sand (\%) & $64.8 \pm 5.2$ & $76.8 \pm 5.0$ & $44.1 \pm 4.6$ & $38.4 \pm 3.8$ & $39.7 * * *$ & NS \\
\hline Moisture (\%) & $34.2 \pm 4.6$ & $23.6 \pm 1.3$ & $73.6 \pm 2.9$ & $61.9 \pm 1.3$ & $121.6 * * *$ & $10.0 * *$ \\
\hline Organic matter (\%) & $5.9 \pm 3.1$ & $2.3 \pm 0.3$ & $30.9 \pm 4.8$ & $18.9 \pm 4.6$ & $31.6 * * *$ & $4.5^{*}$ \\
\hline Carbon $\left(\mathrm{g} \mathrm{kg}^{-1}\right)$ & $30.4 \pm 14.3$ & $13.6 \pm 2.8$ & $144.2 \pm 16.4$ & $88.6 \pm 19.3$ & $41.8^{* * *}$ & $6.1^{*}$ \\
\hline Nitrogen $\left(\mathrm{g} \mathrm{kg}^{-1}\right)$ & $1.62 \pm 1.05$ & $0.22 \pm 0.05$ & $7.96 \pm 1.09$ & $4.43 \pm 1.21$ & $29.7 * * *$ & $6.5^{*}$ \\
\hline $\mathrm{pH}$ & $6.80 \pm 0.12$ & $6.85 \pm 0.22$ & $6.19 \pm 0.07$ & $5.95 \pm 0.14$ & $24.8^{* * *}$ & NS \\
\hline
\end{tabular}

The comparisons shown in this table do not account for site age. The two columns on the right show ANOVA $F$ statistics with asterisks to represent level of significance: ${ }^{*} P<0.05 ;{ }^{* * P}<0.01 ;{ }^{* *} P<0.001$. The interactions between wetland type and soil depth were not significant. 


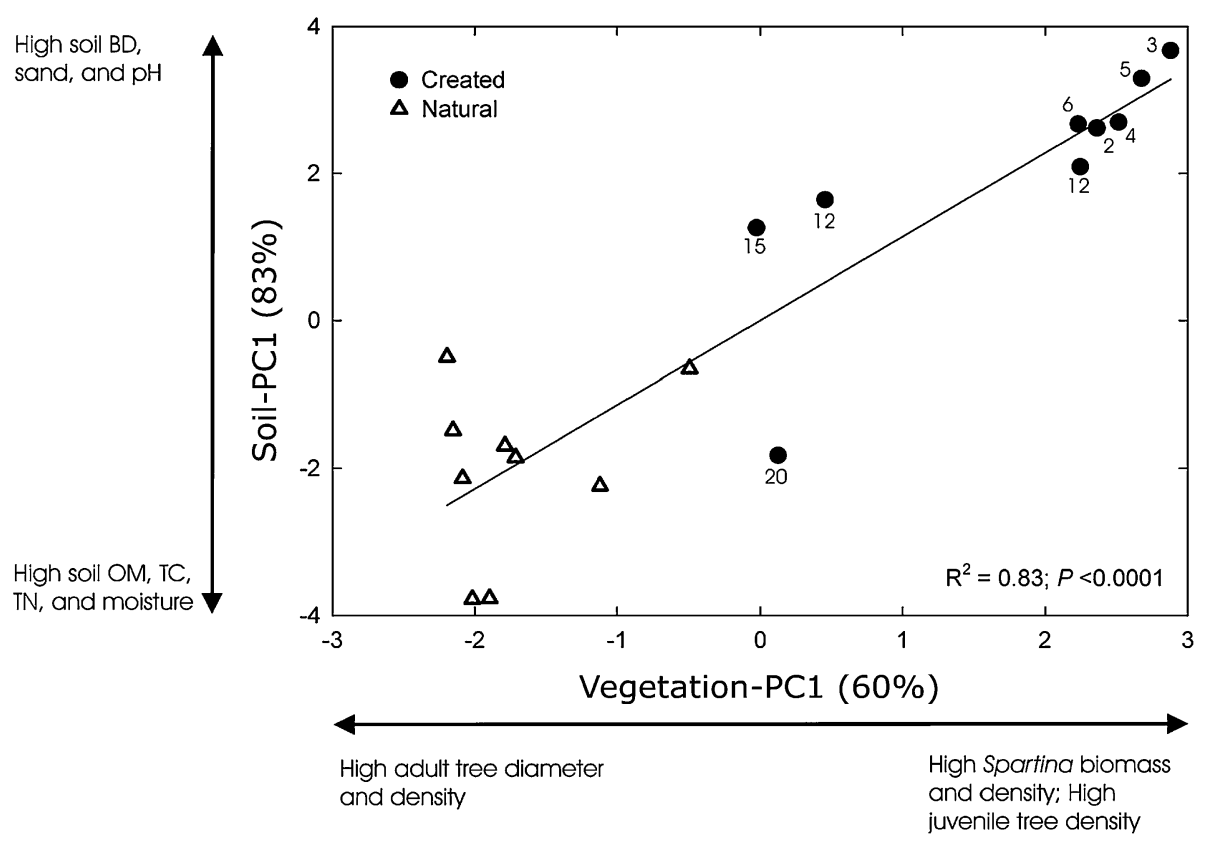

Figure 7. Relationship between the two separate soil and vegetation principal component analyses (PCA). The horizontal axis (vegetation-PC1) represents the site score results for the vegetation PCA, and the vertical axis (soil-PC1) represents the site score results for the soil PCA. The number next to each created wetland site score identifies the site age. The text adjacent to each axis indicates the relationship between each PCA axis and the soil or vegetation variables. Soil abbreviations are as follows: BD bulk density, sand sand content, OM organic matter, TC total carbon, TN total nitrogen, moisture moisture content.

establishment and growth (Lewis and Dunstan 1975; Milbrandt and Tinsley 2006; McKee and others 2007b; Gedan and Silliman 2009; Smith and others 2009; Huxham and others 2010; Kumara and others 2010). Prior experimental studies in mangrove forest gaps indicate that herbaceous species can facilitate mangrove establishment and growth (Milbrandt and Tinsley 2006; McKee and others 2007b). Some of the facilitative mechanisms provided by herbaceous vegetation within mangroves include trapping mangrove propagules, providing structural support for mangrove seedlings, and alleviating stressful physicochemical conditions that impact survival and growth (for example, low oxygen levels, high temperatures) (McKee and others 2007b).

In Tampa Bay, several reports have indicated that, during mangrove wetland restoration and creation, planted native salt marsh grasses (primarily $S$. alterniflora) can facilitate mangrove recruitment and establishment once the appropriate hydrology is established (Lewis and Dunstan 1975; Lewis 1982, 1990; Crewz and Lewis 1991; Lewis and others 2005; Shafer and Roberts 2008; Smith and others 2009). The starting conditions at our study sites were $S$. alterniflora-dominated marshes within which mangrove recruitment and growth occurred naturally; hence, our study quantifies the transition from salt marsh to mangrove forest via natural recruitment in a restoration or creation context. Across the 20-year chronosequence, the vegetation transitioned from a planted herbaceous layer dominated by $S$. alterniflora to a mangrove forest community dominated by $R$. mangle, $L$. racemosa, and/or A. germinans. The planted salt marsh layer was abundant and dominant at younger sites but absent from older sites, presumably due to shading as a mangrove tree canopy developed. Natural mangrove recruitment was high and juvenile mangrove tree density and height increased initially but then began to decrease as the adult mangrove tree layer developed. In contrast, the density and diameter of adult mangrove trees were still increasing in the second decade of the chronosequence, providing evidence that, despite a positive trajectory, these created mangrove forests are not yet fully developed. As individual adult trees become more mature and dominant, the mangrove forest should begin to self-thin and adult tree densities should decline (Fromard and others 1998; Bosire and others 2008; Alongi 2011). In a study of eighteen mangrove mitigation wetlands in Florida with ages ranging from 13- to 23-years-old, Shafer and Roberts (2008) noted similar results; despite a positive plant community developmental trajectory, they found 


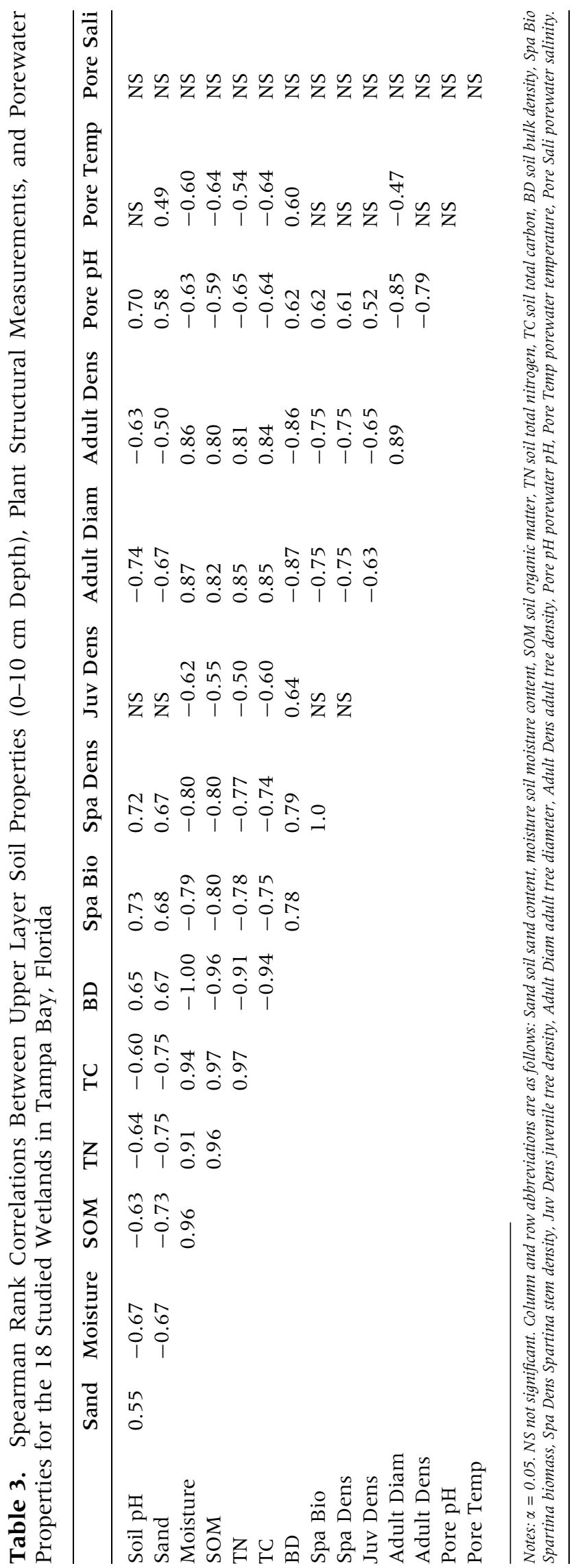


smaller forest canopy heights, smaller basal areas, and higher stem densities in mitigation sites than in natural mangrove forests.

Experimental studies testing the true efficacy and mechanisms responsible for $S$. alterniflora facilitation of mangrove forest development have not yet been conducted. In certain environments, $S$. alterniflora can compete with mangrove seedlings (McKee and Rooth 2008; Smith and others 2009; Zhang and others 2012). Also, where positive interactions with nurse plants have been documented, the results may be species specific to both the nurse plant (for example, Batis, Distichlis, Sesuvium, Spartina spp.) and the mangrove species (McKee and others 2007a), strongly suggesting that region-specific screenings of potential facilitating species be undertaken to ensure maximum restoration success. Finally, positive effects on mangrove recruitment may arise from interactions with other organisms that are difficult to distinguish from S. alterniflora effects, such as those of burrowing Uca spp. (that is, fiddler crabs; Bertness 1985). At a created wetland site in Tampa Bay that utilized S. alterniflora as a nurse plant, Smith and others (2009) determined that mangrove seedling growth was more enhanced by fiddler crab burrowing.

\section{Soil Change After Mangrove Wetland Creation: Peat Development and Comparisons Between Natural and Created Mangrove Wetlands}

Wetland soils provide the physicochemical substrates that maintain biotic communities (for example, microbes, plants, detritivores) and support biogeochemical processes directly related to important ecosystem services (for example, C storage, N removal) (Brady and Weil 1996; Reddy and DeLaune 2008). Natural wetland soils are usually very $\mathrm{C}$-rich relative to upland and marine ecosystems; although wetlands cover less than 10\% of the earth's terrestrial surface (Zedler and Kercher 2005; Mitsch and Gosselink 2007), wetland soils contain roughly one-third of the global soil C pool (Mitsch and Gosselink 2007). However, there are often large differences between restored, created, and natural wetland soils, and many studies in diverse wetland types indicate that it typically takes much time (for example, decades, centuries) for created and restored wetlands to develop soil properties that are equivalent to natural wetlands (Craft and others 2003; Ballantine and Schneider 2009; Hossler and Bouchard 2010; Hossler and others 2011). Because various international, federal, and state regulations stipulate that, in a mitigation context, created and restored wetlands should be functionally equivalent to the natural wetlands they replace, the slow rate of soil functional and structural development following creation and restoration has caused concern (Bruland 2004; Hossler and Bouchard 2010; Hossler and others 2011). Much of this discussion has centered on the equivalent development of SOM and $\mathrm{C}$-dependent soil properties. SOM is a good indicator of soil quality and often a good bulk proxy for biogeochemical properties (Brady and Weil 1996; Bruland and Richardson 2006; Reddy and DeLaune 2008; Sutton-Grier and others 2009; Hossler and others 2011; Wolf and others 2011).

Our primary soil-focused study objectives were to compare soil properties in created and natural mangrove wetland ecosystems and to quantify the rate and trajectory of post-creation soil development with an emphasis on soil properties indicative of peat development (that is, SOM, TC, TN, BD). Mangrove wetlands have tremendous potential for soil $\mathrm{C}$ accumulation and storage due to high productivity and slow decomposition (Alongi 2009; Mcleod and others 2011), and, given the literature on relatively rapid plant-driven soil change in mangrove wetlands (Middleton and McKee 2001; McKee and others 2007a; McKee 2010), we expected that soil development after mangrove wetland creation might be more rapid than in other created wetland types.

Although our data support a positive developmental trajectory in the upper layer $(0-10 \mathrm{~cm})$ of created wetland soils, our data also quantify important differences between created and natural reference site lower soil layers. Literature values for peat layer thickness in natural mangrove wetlands within our study region range between 15 and $90 \mathrm{~cm}$ (Hyde and Huckle 1983; Doolittle and others 1989). At the nine natural reference wetland sites in this study, the peat layer was typically between 25 and 50-cm thick (Figure 3; MJO, unpublished data). In contrast, the initial soils present at the created wetland sites in our study (that is, the younger created wetlands) were characteristic of upland soils or dredge spoil with no peat layer, higher bulk densities, higher sand content, lower SOM, and lower TN and TC (Figures 2, 5, 6; Table 1). In the Tampa Bay region, created tidal wetlands are typically established by removing the upper layer of upland soil or dredge spoil and grading the site until the appropriate tidal elevation is reached. Hence, the initial soils at created wetland sites are typically upland soils and/or dredge spoil. Across the chronosequence represented by our sites, a peat layer eventually developed in the 
upper $10-\mathrm{cm}$ of soil; by year 20 , the soil properties we measured in the upper layer of the created sites were equivalent to soil properties within the upper layer of the natural reference wetlands (that is, equivalent SOM, TC, TN, bulk density, sand content, moisture content; Figures 2, 5). Coupled plant and soil changes were clearly evident (Figure 7; Table 3), and we expect that mangrove forest growth was the driver of the rapid soil change observed in the upper soil layer. Most of the soil change occurred in the second decade of the chronosequence simultaneously with adult mangrove tree growth. Adult mangrove tree variables were strongly correlated with SOM, TN, TC, and bulk density, and our multivariate analyses indicated that more mature soil characteristics (that is, greater peat development) were closely tied to mangrove forest development.

However, soil change in the upper layer did not extend far into the lower soil layer $(10-30 \mathrm{~cm})$; there was no age-related trajectory for soil properties in the lower soil layer of created mangrove wetlands, and the differences between the lowerlayer soil properties in created and natural reference wetland sites were large (that is, at the created wetlands: more sand, higher bulk densities, lower SOM, lower \% moisture, higher porewater temperatures, lower TC and TN). Porewater temperature and $\mathrm{pH}$ differences between the created and natural wetland sites in our study were also large (that is, higher temperatures and $\mathrm{pH}$ at the created wetlands, presumably due to increased solar exposure and lower organic matter, respectively). In a study conducted in southwest Florida, McKee and Faulkner (2000) also noted soil and porewater physicochemical differences between restored and natural mangrove wetland sites and highlighted the importance of establishing the appropriate hydro-edaphic conditions for restoring forest structural properties and biogeochemical functions (for example, carbon and nitrogen cycling). In a study conducted in western Mexico, Vovides and others (2010) found that nitrogen fixation rates were similar in restored and natural mangrove wetland soils. Additional research is needed to: (1) determine if and when properties of the lower soil layer of created mangrove wetlands will become equivalent to natural reference mangrove wetlands; and (2) assess the functional implications of lower soil layer and porewater differences between created and natural mangrove wetlands.

Due to the high rate of $\mathrm{C}$ burial in natural mangrove wetlands (Mcleod and others 2011), there has been interest in the potential for rapid C accumulation and longer-term $\mathrm{C}$ sequestration through mangrove wetland restoration, creation, and/or conservation efforts (see Discussion in Bouillon and others 2009; Alongi 2011), especially in relation to their inclusion in $\mathrm{C}$-focused payment for ecosystem service markets (Laffoley and Grimsditch 2009; Danone Fund for Nature 2010; Murray and others 2010; but see Alongi 2011). The rates of $\mathrm{C}$ and $\mathrm{N}$ accumulation in the top $10 \mathrm{~cm}$ of soil at the created mangrove wetland sites in our study $\left(218 \mathrm{~g} \mathrm{C} \mathrm{m}^{-2} \mathrm{y}^{-1}\right.$ and $13 \mathrm{~g} \mathrm{~N} \mathrm{~m}^{-2} \mathrm{y}^{-1}$, respectively; Figure 6) fall within the range of values measured for other natural, restored, and created wetlands. The $\mathrm{C}$ accumulation rate is very close to the global mean for natural mangrove forests and salt marshes (226 and $218 \mathrm{~g} \mathrm{C} \mathrm{m}^{-2} \mathrm{y}^{-1}$, respectively) (Chmura and others 2003; Mcleod and others 2011). For comparison, we also present soil $\mathrm{C}$ and $\mathrm{N}$ accumulation rates from other restored or created wetland types: (1) restored prairie potholes (north-central North America; $305 \mathrm{~g} \mathrm{C} \mathrm{m}^{-2} \mathrm{y}^{-1}$ ) (Euliss and others 2006); (2) created freshwater marshes in Ohio (181-193 $\mathrm{g} \mathrm{C} \mathrm{m}^{-2} \mathrm{y}^{-1}$; $16 \mathrm{~g} \mathrm{~N} \mathrm{~m}^{-2} \mathrm{y}^{-1}$ ) (Anderson and Mitsch 2006); and (3) created salt marshes in North Carolina (99-125 g C m${ }^{-2} \mathrm{y}^{-1}$; 7-12 $\mathrm{g} \mathrm{N} \mathrm{m}^{-2} \mathrm{y}^{-1}$ ) (Craft and others 1999). We stress that the rate of soil C and $\mathrm{N}$ accumulation in created and restored mangrove forests will likely change as mangrove forests mature (Odum 1969; Alongi 2011), and additional studies are needed to better quantify the spatial and temporal variability in soil $\mathrm{C}$ and $\mathrm{N}$ accumulation. Interestingly, our soil $\mathrm{N}$ accumulation results support data from a greenhouse experiment indicating high soil $\mathrm{N}$ enrichment after mangrove colonization of sandy substrates (Inoue and others 2011).

Our results indicate that the time to equivalence for the soil C pool in the upper $10-\mathrm{cm}$ of created mangrove wetlands can be relatively rapid ( $\sim 20$ years) and faster than most other wetland types. For comparison, we present estimates of the amount of time for soil $\mathrm{C}$ pools to become equivalent to natural reference wetlands in several other wetland types: created brackish marshes in NC (70-90 years) (Craft and others 2002), restored freshwater marshes in New York (>55 years) (Ballantine and Schneider 2009), created freshwater marshes in Ohio ( 300 years) (Hossler and Bouchard 2010), created salt marshes in Louisiana ( 32 years) (Edwards and Proffitt 2003), and created herbaceous wetlands in Virginia ( $\sim 7$ years) (Wolf and others 2011). Our results coincide with a meta-analysis of wetland restoration outcomes which found that wetland ecosystem recovery can be more rapid in warmer climates and in wetlands that are linked to tidal or riverine flows 
(Moreno-Mateos and others 2012). Although the rate of upper soil layer development in this study was faster than in many other wetland types, the rate of development is still slow relative to the time frames utilized in most regulatory or environmental management settings (Zedler 1996; Hossler and others 2011).

Compensating for the Loss of C Burial in Natural Mangrove Wetlands via Mangrove Wetland Creation or Restoration: How to Evaluate Replacement Scenarios?

Can the C burial potential of created or restored mangrove wetlands be used to compensate for $\mathrm{C}$ burial losses due to prior mangrove wetland losses? If so, how much area and time would be required? Here, we present a simplistic approach to answering these questions with the caveat that we focus solely on $\mathrm{C}$ burial and do not include other components of the $\mathrm{C}$ cycle (for example, gas efflux due to peat decomposition) or other ecosystem services provided by mangrove wetlands. A holistic approach to compensatory calculations would include and bundle several ecosystem functions and services together. Given these caveats and assuming that: (1) the global mangrove wetland area was $187,940 \mathrm{~km}^{2}$ in 1980 (FAO 2007); (2) mangrove wetlands were lost at a mean rate of $0.8 \%$ per year during the period 1980-2011 (derived from a rate of 1.04 in the 1980 s, 0.72 in the 1990s, and 0.77 from 2000-2005; FAO 2007); and (3) the mean soil C burial rate in natural mangrove wetlands is $0.000226 \mathrm{Tg} \mathrm{C} \mathrm{km} \mathrm{y}^{-2} \mathrm{y}^{-1}$ (Mcleod and others 2011), we estimate that the amount of $C$ burial that has not occurred due to mangrove wetland loss in the 31 year period between 1980 and 2011 is $165 \mathrm{Tg} \mathrm{C}$. The future (that is, post-2011) annual C burial that these lost mangrove wetlands (that is, the cumulative mangrove area lost between 1980 and 2011: 42,500 $\mathrm{km}^{2}$ ) would have supported is $9.6 \mathrm{Tg} \mathrm{C} \mathrm{y}^{-1}$. Using these values in combination with the rate of soil $\mathrm{C}$ burial in created mangrove wetlands of $0.000218 \mathrm{Tg} \mathrm{C} \mathrm{km}^{-2} \mathrm{y}^{-1}$ from this study (Figure 6), we evaluated the following replacement scenarios: (1) a 1:1 ratio (that is, wetland area created: wetland area lost) which includes $42,500 \mathrm{~km}^{2}$ of created mangrove wetland habitat; (2) a 1.5:1 ratio which includes $63,750 \mathrm{~km}^{2}$ of created mangrove wetland habitat; and (3) a 2:1 ratio which includes $85,000 \mathrm{~km}^{2}$ of created mangrove wetland habitat. Due to the large initial deficit in C burial from prior mangrove wetland losses and the similar annual C burial rates in created and natural

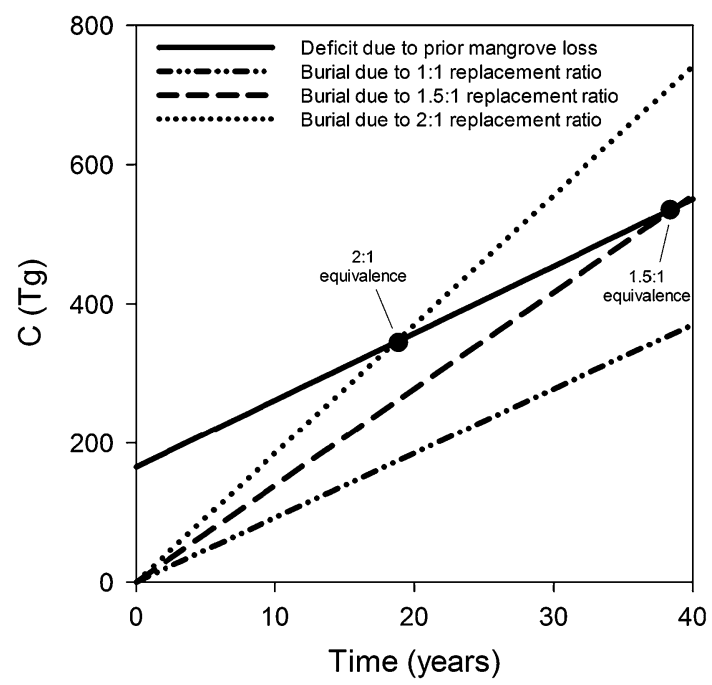

Figure 8. Relationship between $\mathrm{C}$ burial deficit due to past mangrove wetland losses and potential future $C$ burial gain due to three different mangrove wetland creation replacement scenarios. Replacement ratios refer to the ratio of mangrove wetland area created to mangrove wetland area lost. The intersection nodes identify when the $\mathrm{C}$ burial gain of a given replacement scenario has become equivalent to the $\mathrm{C}$ burial deficit due to past mangrove losses.

mangrove wetlands, our results indicate that the $1: 1$ replacement ratio will never make up for past mangrove wetland losses; however, our calculations indicate that the $1.5: 1$ and 2:1 replacement ratios will make up for the $\mathrm{C}$ burial deficit in 37 and 19 years, respectively (Figure 8).

Our evaluation of replacement ratios are included solely to present an initial (but still incomplete) approach for developing compensatory calculations for $\mathrm{C}$ burial losses associated with mangrove wetland loss and mangrove wetland creation and/or restoration. The $\mathrm{C}$ burial rate used for created mangrove wetlands in these calculations comes solely from this study and is based on mangrove wetlands within a single geographic region near the northern distribution limit for mangroves; mangrove wetlands in different geomorphic settings, different hydrological or climatic regimes, and of different successional classes would likely have different rates of $\mathrm{C}$ burial (Alongi 2011). Thus, additional studies are needed to better quantify the global potential for and range of $C$ burial in created and restored mangrove wetlands. Of tremendous importance is the fact that our calculations do not include $\mathrm{CO}_{2}$ and $\mathrm{CH}_{4}$ effluxes due to peat decomposition after mangrove wetland conversion to other land uses. Due to the large amount of $\mathrm{C}$ buried in mangrove wetland peat, $\mathrm{CO}_{2}$ and $\mathrm{CH}_{4}$ effluxes associated with decomposition of cleared, converted, and/or disturbed mangrove wetland peat 
can be high (Strangmann and others 2008; Lovelock and others 2011 ), and we expect that the inclusion of peat decomposition (that is, greenhouse gas production) in these scenarios would require that a larger replacement ratio and/or longer time period be required for $\mathrm{C}$ burial compensation.

\section{Conclusions}

Our results quantify the rate and trajectory of ecosystem development in created mangrove wetlands. Across a 20-year chronosequence, the vegetation transitioned from a planted $S$. alterniflora salt marsh community to a naturally recruited mangrove forest. Our data highlight key differences between the ecosystem properties present in created and natural mangrove wetlands (for example, lower soil layer physicochemical properties, mangrove forest structure) indicating that ecosystem development in created wetland sites with respect to vegetation and soil equivalency is not yet complete. However, our results also quantify a positive developmental trajectory that reflects tightly linked and relatively rapid plant-soil change (that is, mangrove forest development occurring simultaneously with upper soil layer peat development, C and $\mathrm{N}$ accumulation, bulk density change). Ecosystem development in created mangrove wetlands may be faster than in many other wetland ecosystem types but still slower than timescales envisioned within most regulatory or environmental management settings. Interestingly, the rate of soil carbon accumulation across the 20 -year chronosequence was very close to the global mean for natural mangrove wetlands. Of course, longer-term studies within individual sites and/or the inclusion of a greater number of differentially aged sites (particularly older sites) would improve our estimates of the rate of trajectory of ecosystem development following mangrove wetland creation. Collectively, our findings help characterize the rate and trajectory of above- and belowground changes associated with mangrove forest development in created wetlands and provide valuable information to environmental managers planning to sustain existing mangrove wetlands or mitigate for past/ future mangrove wetland losses.

\section{ACKNOWLEDGMENTS}

This research was completed with the tremendous support of many individuals and organizations. For their permission to conduct research on their lands, we thank the Environmental Protection Commission of Hillsborough County, Manatee County
Natural Resources Department, Southwest Florida Water Management District, Tampa Bay Electric Company, Cockroach Bay Aquatic Preserve, and Terra Ceia Aquatic Preserve. For their logistical support, we thank Richard Sullivan, Max Dersch, Brandt Henningsen, Wendy Anastasio, Randy Runnels, and Ross Dickerson. We are very grateful to Montseratt Montero Fernandez, Rebecca Moss, David Boniche, Bernard Lilavois, John Dittmar, Jason Pietroski, Garrett Pangle, Coleen Elonen, Terri Jicha, and Heather Smith for their assistance in the laboratory and/or field. This manuscript was improved by comments from RR Lewis, KL McKee, the subject-matter editor, and two anonymous reviewers. The views expressed in this paper are those of the authors and do not necessarily reflect the views or policies of the U.S. Environmental Protection Agency. Any use of trade, product, or firm names is for descriptive purposes only and does not imply endorsement by the United States Government.

\section{REFERENCES}

Alongi DM. 2009. The energetics of mangrove forests. Dordrecht: Springer. $216 \mathrm{pp}$.

Alongi DM. 2011. Carbon payments for mangrove conservation: ecosystem constraints and uncertainties of sequestration potential. Environ Sci Policy 14:462-70.

Alongi DM, Sasekumar A, Chong VC, Pfitzner J, Trott LA, Tirendi F, Dixon P, Brunskill GJ. 2004. Sediment accumulation and organic material flux in a managed mangrove ecosystem: estimates of land-ocean-atmosphere exchange in peninsular Malaysia. Mar Geol 208:383-402.

Alongi DM, Trott LA, Rachmansyah TF, Tirendi F, McKinnon $\mathrm{AD}$, Undu MC. 2008. Growth and development of mangrove forests overlying smothered coral reefs, Sulawesi and Sumatra, Indonesia. Mar Ecol Prog Ser 370:97-109.

Alongi DM, Wattayakorn G, Pfitzner J, Tirendi F, Zagorskis I, Brunskill GJ, Davidson A, Clough BF. 2001. Organic carbon accumulation and metabolic pathways in sediments of mangrove forests in southern Thailand. Mar Geol 179:85-103.

Anderson CJ, Mitsch WJ. 2006. Sediment, carbon, and nutrient accumulation at two 10-year-old created riverine marshes. Wetlands 26:779-92.

Ballantine K, Schneider R. 2009. Fifty-five years of soil development in restored freshwater depressional wetlands. Ecol Appl 19:1467-80.

Barbier EB, Hacker SD, Kennedy C, Koch EW, Stier AC, Silliman BR. 2010. The value of estuarine and coastal ecosystem services. Ecol Monogr 81:169-93.

Bedford BL, Walbridge MR, Aldous A. 1999. Patterns in nutrient availability and plant diversity of temperate North American wetlands. Ecology 80:2151-69.

Bertness MD. 1985. Fiddler crab regulation of Spartina alterniflora production on a New England salt marsh. Ecology 66:1042-55.

Blake GR, Hartge KH. 1986. Bulk density. In: Klute A, Eds. Methods of soil analysis. Part 1. Physical and mineralogical methods. Madison (WI): American Society of Agronomy. pp 363-75. 
Bosire JO, Dahdouh-Guebas F, Walton M, Crona BI, Lewis RR, Field C, Kairo JG, Koedam N. 2008. Functionality of restored mangroves: a review. Aquat Bot 89:251-9.

Bouillon S, Rivera-Monroy V, Twilley RR, Kairo JG. 2009. Mangroves. In: Laffoley D, Grimsditch G, Eds. The management of natural coastal carbon sinks. Gland: IUCN. pp 13-20.

Brady NC, Weil RR. 1996. The nature and properties of soils. Upper Saddle River (NJ): Prentice-Hall. 960 pp.

Bruland GL. 2004. An observational, geostatistical, and experimental assessment of edaphic properties and processes in created, restored, and natural wetlands of the Southeastern Coastal Plain. Ph.D. Dissertation. Duke University, Durham, NC.

Bruland GL, Richardson CJ. 2006. Comparison of soil organic matter in created, restored and paired natural wetlands in North Carolina. Wetlands Ecol Manag 14:245-51.

Chmura GL, Anisfeld SC, Cahoon DR, Lynch JC. 2003. Global carbon sequestration in tidal, saline wetland soils. Global Biogeochem Cycles 17:1111.

Craft C, Broome S, Campbell C. 2002. Fifteen years of vegetation and soil development after brackish water marsh creation. Restor Ecol 10:248-58.

Craft C, Megonigal P, Broome S, Stevenson J, Freese R, Cornell J, Zheng L, Sacco J. 2003. The pace of ecosystem development of constructed Spartina alterniflora marshes. Ecol Appl 13: 1417-32.

Craft C, Reader J, Sacco JN, Broome SW. 1999. Twenty-five years of ecosystem development of constructed Spartina alterniflora (Loisel) marshes. Ecol Appl 9:1405-19.

Crewz DW, Lewis RR. 1991. An evaluation of historical attempts to establish emergent vegetation in marine wetlands in Florida. Florida Sea Grant Publication No. 60. Gainesville (FL): Florida Sea Grant College. 79 pp.

Danone Fund for Nature. 2010. Achieving carbon offsets through mangroves and other wetlands. Gland: Danone Group/IUCN/Ramsar Convention Secretariat. $87 \mathrm{pp}$.

Donato DC, Kauffman JB, Murdiyarso D, Kurnianto S, Stidham M, Kanninen M. 2011. Mangroves among the most carbonrich forests in the tropics. Nat Geosci 4:293-7.

Doolittle JA, Schellentrager G, Ploetz S. 1989. Soil survey of Hillsborough County. La Belle: Soil Conservation Service. 168 pp.

Duarte CM, Cebrián J. 1996. The fate of marine autotrophic production. Limnol Oceanogr 41:1758-66.

Edwards KR, Proffitt CE. 2003. Comparison of wetland structural characteristics between created and natural salt marshes in southwest Louisiana, USA. Wetlands 23:344-56.

Ellison AM. 2000. Mangrove restoration: do we know enough? Restor Ecol 8:219-29.

Eshel G, Levy GJ, Mingelgrin U, Singer MJ. 2004. Critical evaluation of the use of laser diffraction for particle-size distribution analysis. Soil Sci Soc Am J 68:736-43.

Euliss NH, Gleason RA, Olness A, McDougal RL, Murkin HR, Robarts RD, Bourbonniere RA, Warner BG. 2006. North American prairie wetlands are important nonforested landbased carbon storage sites. Sci Total Environ 361:179-88.

Ewel KC, Twilley RR, Ong JE. 1998. Different kinds of mangrove forests provide different goods and services. Global Ecol Biogeogr Lett 7:83-94.

FAO. 2007. The world's mangroves 1980-2005: a thematic study prepared in the framework of the global forest resources assessment 2005. FAO forestry paper 153. Rome: Forestry Department, FAO. 77 pp.
Friess DA, Krauss KW, Hortsman EM, Balke T, Bouma TJ, Galli D, Webb EL. 2011. Are intertidal wetlands created equal? Bottlenecks, thresholds and knowledge gaps to mangrove and saltmarsh ecosystems. Biol Rev. doi:10.1111/j.1469-185X.2011. 00198.x.

Fromard F, Puig H, Mougin E, Marty G, Betoulle JL, Cadamuro L. 1998. Structure, above-ground biomass and dynamics of mangrove ecosystems: new data from French Guiana. Oecologia 115:39-53.

Gedan KB, Silliman BR. 2009. Using facilitation theory to enhance mangrove restoration. Ambio 38:109.

Giri C, Ochieng E, Tieszen LL, Zhu Z, Singh A, Loveland T, Masek J, Duke N. 2011. Status and distribution of mangrove forests of the world using earth observation satellite data. Glob Ecol Biogeogr 20:154-9.

Giri C, Zhu Z, Tieszen LL, Singh A, Gillette S, Kelmelis JA. 2008. Mangrove forest distributions and dynamics (1975-2005) of the tsunami-affected region of Asia. J Biogeogr 35:519-28.

Hossler K, Bouchard V. 2010. Soil development and establishment of carbon-based properties in created freshwater marshes. Ecol Appl 20:539-53.

Hossler K, Bouchard V, Fennessy MS, Frey SD, Anemaet E, Herbert E. 2011. No-net-loss not met for nutrient function in freshwater marshes: recommendations for wetland mitigation policies. Ecosphere 2: art82.

Huxham M, Kumara MP, Jayatissa LP, Krauss KW, Kairo J, Langat J, Mencuccini M, Skov MW, Kirui B. 2010. Intra- and interspecific facilitation in mangroves may increase resilience to climate change threats. Philos Trans R Soc B 365:2127-35.

Hyde AG, Huckle HF. 1983. Soil survey of Manatee County. La Belle: Soil Conservation Service. 159 pp.

Inoue T, Nohara S, Matsumoto K, Anzai Y. 2011. What happens to soil chemical properties after mangrove plants colonize? Plant Soil 346:259-73.

Kaly UL, Jones GP. 1998. Mangrove restoration: a potential tool for coastal management in tropical developing countries. Ambio 27:656-61.

Karam A. 1993. Chemical properties of organic soils. In: Carter MR, for Canadian Society of Soil Science, Eds. Soil sampling and methods of analysis. London: Lewis Publishers. pp 45971.

Krauss KW, Lovelock CE, McKee KL, López-Hoffman L, Ewe SML, Sousa WP. 2008. Environmental drivers in mangrove establishment and early development: a review. Aquat Bot 89:105-27.

Kumara MP, Jayatissa LP, Krauss KW, Phillips DH, Huxham M. 2010. High mangrove density enhances surface accretion, surface elevation change, and tree survival in coastal areas susceptible to sea-level rise. Oecologia 164:545-53.

Laffoley D, Grimsditch G. 2009. The management of natural coastal carbon sinks. Gland: IUCN. p 53 pp.

Lewis RR. 1982. Low marshes, Peninsular Florida. In: Lewis RR, Ed. Creation and restoration of coastal plain communities. Boca Raton (FL): CRC Press. p 147-52.

Lewis RR. 1990. Creation and restoration of coastal plain wetlands in Florida. In: Kusler JA, Kentula ME, Eds. Wetland creation and restoration: the status of the science. Washington (DC): Island Press. p 73-101.

Lewis RR. 2005. Ecological engineering for successful management and restoration of mangrove forests. Ecol Eng 24:403-18.

Lewis RR. 2009. Methods and criteria for successful mangrove forest restoration. In: Perillo GME, Wolanski E, Cahoon DR, 
Brinson MM, Eds. Coastal wetlands: an integrated ecosystem approach. Oxford: Elsevier. p 787-800.

Lewis RR, Dunstan FM. 1975. The possible role of Spartina alterniflora Loisel. In: Establishment of mangroves in Florida. Proceedings of the second annual conference on restoration of coastal vegetation in Florida. pp 82-100.

Lewis RR, Estevez ED. 1988. The ecology of Tampa Bay, Florida: an estuarine profile. U.S. Fish Wildl. Serv. Biol. Rep. 85(7.18): 132 pp.

Lewis RR, Gilmore RG. 2007. Important considerations to achieve successful mangrove forest restoration with optimum fish habitat. Bull Mar Sci 80:823-37.

Lewis RR, Hodgson AB, Mauseth GS. 2005. Project facilitates the natural reseeding of mangrove forests (Florida). Ecol Restor 23:276-7.

Lovelock CE, Ruess RW, Feller IC. $2011 . \mathrm{CO}_{2}$ efflux from cleared mangrove peat. PLoS ONE 6:e21279.

Lovelock CE, Sorrell BK, Hancock N, Hua Q, Swales A. 2010. Mangrove forest and soil development on a rapidly accreting shore in New Zealand. Ecosystems 13:437-51.

Matthews JW, Spyreas G. 2010. Convergence and divergence in plant community trajectories as a framework for monitoring wetland restoration progress. J Appl Ecol 47:1128-36.

McCune B, Grace JB. 2002. Analysis of ecological communities. Gleneden Beach (OR): MjM Software Design. p 300 pp.

McGill WB, Figueiredo CT. 1993. Total nitrogen. In: Carter MR, for Canadian Society of Soil Science, Eds. Soil sampling and methods of analysis. London: Lewis Publishers. pp 201-11.

McKee KL. 2010. Biophysical controls on accretion and elevation change in Caribbean mangrove ecosystems. Estuar Coast Shelf Sci 91:475-83.

McKee KL, Cahoon DR, Feller IC. 2007a. Caribbean mangroves adjust to rising sea level through biotic controls on change in soil elevation. Glob Ecol Biogeogr 16:545-56.

McKee KL, Faulkner PL. 2000. Restoration of biogeochemical function in mangrove forests. Restor Ecol 8:247-59.

McKee KL, Mendelssohn IA, Hester MW. 1988. Reexamination of pore water sulfide concentrations and redox potentials near the aerial roots of Rhizophora mangle and Avicennia germinans. Am J Bot 75:1352-9.

McKee KL, Rooth JE. 2008. Where temperate meets tropical: multi-factorial effects of elevated $\mathrm{CO}_{2}$, nitrogen enrichment, and competition on a mangrove-salt marsh community. Glob Change Biol 14:971-84.

McKee KL, Rooth JE, Feller IC. 2007b. Mangrove recruitment after forest disturbance is facilitated by herbaceous species in the Caribbean. Ecol Appl 17:1678-93.

Mcleod E, Chmura GL, Bouillon S, Salm R, Björk M, Duarte CM, Lovelock CE, Schlesinger WH, Silliman BR. 2011. A blueprint for blue carbon: toward an improved understanding of the role of vegetated coastal habitats in sequestering $\mathrm{CO}_{2}$. Front Ecol Environ 9:552-60.

Middleton BA, McKee KL. 2001. Degradation of mangrove tissues and implications for peat formation in Belizean island forests. J Ecol 89:818-28.

Milbrandt EC, Tinsley MN. 2006. The role of saltwort (Batis maritima L.) in regeneration of degraded mangrove forests. Hydrobiologia 568:369-77.

Mitsch WJ, Gosselink JG. 2007. Wetlands. New York: Wiley. 582 pp.

Moreno-Mateos D, Power ME, Comín FA, Yockteng R. 2012. Structural and functional loss in restored wetland ecosystems. PLoS Biol 10:e1001247.
Morrisey DJ, Skilleter GA, Ellis JI, Burns BR, Kemp CE, Burt K. 2003. Differences in benthic fauna and sediment among mangrove (Avicennia marina var. australasica) stands of different ages in New Zealand. Estuar Coast Shelf Sci 56:581-92.

Murray BC, Jenkins WA, Sifleet S, Pendelton L, Baldera A. 2010. Payments for blue carbon: potential for protecting threatened coastal habitats. Policy brief. Durham: Nicholas Institute for Environmental Policy Solutions. Duke University.

Odum EP. 1969. The strategy of ecosystem development. Science 164:262-70.

Pickett STA, Ostfeld RS. 1989. Space-for-time substitution as an alternative to long-term studies. In: Likens GE, Ed. Long-term studies in ecology: approaches and alternatives. New York: Springer. p 110-35.

Reddy KR, DeLaune RD. 2008. Biogeochemistry of wetlands: science and applications. Boca Raton (FL): CRC Press. p 774 pp.

Ren H, Jian S, Lu H, Zhang Q, Shen W, Han W, Yin Z, Guo Q. 2008. Restoration of mangrove plantations and colonisation by native species in Leizhou bay, South China. Ecol Res 23:401-7.

Shafer DJ, Roberts TH. 2008. Long-term development of tidal mitigation wetlands in Florida. Wetlands Ecol Manag 16:23-31.

Smith NF, Wilcox C, Lessmann JM. 2009. Fiddler crab burrowing affects growth and production of the white mangrove (Laguncularia racemosa) in a restored Florida coastal marsh. Mar Biol 156:2255-66.

Spalding M, Kainuma M, Collins L. 2010. World atlas of mangroves. London: Earthscan. p 319 pp.

Stagg CL, Mendelssohn IA. 2010. Restoring ecological function to a submerged salt marsh. Restor Ecol 18:10-17.

Strangmann A, Bashan Y, Giani L. 2008. Methane in pristine and impaired mangrove soils and its possible effect on establishment of mangrove seedlings. Biol Fertil Soils 44:511-19.

Sutton-Grier AE, Ho M, Richardson CJ. 2009. Organic amendments improve soil conditions and denitrification in a restored riparian wetland. Wetlands 29:343-52.

Tiessen H, Moir JO. 1993. Total and organic carbon. In: Carter MR, for Canadian Society of Soil Science, Eds. Soil sampling and methods of analysis. London: Lewis Publishers. pp 187-199.

Tomlinson PB. 1995. The botany of mangroves. Cambridge: Cambridge University Press. p 413 pp.

Vovides AG, Bashan Y, López Portillo JA, Guevara R. 2010. Nitrogen fixation in preserved, reforested, naturally regenerated and impaired mangroves as an indicator of functional restoration in mangroves in an arid region of Mexico. Restor Ecol 19:236-44.

Wolf KL, Ahn C, Noe GB. 201 1. Development of soil properties and nitrogen cycling in created wetlands. Wetlands 31:699-712.

Zedler JB. 1996. Ecological issues in wetland mitigation: an introduction to the forum. Ecol Appl 6:33-7.

Zedler JB. 2000. Progress in wetland restoration ecology. Trends Ecol Evol 15:402-7.

Zedler JB, Callaway JC. 1999. Tracking wetland restoration: do mitigation sites follow desired trajectories? Restor Ecol 7:69-73.

Zedler JB, Kercher S. 2005. Wetland resources: status, trends, ecosystem services, and restorability. Annu Rev Environ Resour 30:39-74.

Zhang Y, Huang G, Wang W, Chen L, Lin G. 2012. Interactions between mangroves and exotic Spartina in an anthropogenically-disturbed estuary in southern China. Ecology. doi:10.1890/11-1302.1. 